University of Rhode Island

DigitalCommons@URI

Open Access Dissertations

1999

\title{
Toni Morrison: Rethinking the Past in a Postcolonial Context
}

Hanan Abdullatif

University of Rhode Island

Follow this and additional works at: https://digitalcommons.uri.edu/oa_diss

\section{Recommended Citation}

Abdullatif, Hanan, "Toni Morrison: Rethinking the Past in a Postcolonial Context" (1999). Open Access Dissertations. Paper 389.

https://digitalcommons.uri.edu/oa_diss/389

This Dissertation is brought to you for free and open access by DigitalCommons@URI. It has been accepted for inclusion in Open Access Dissertations by an authorized administrator of DigitalCommons@URI. For more information, please contact digitalcommons-group@uri.edu. 
TONI MORRISON: RETHINKING THE PAST IN A

POSTCOLONIAL CONTEXT

BY

HANAN ABDULLATIF

A DISSERTATION SUBMITTED IN PARTIAL FULFILLMENT OF THE

REQUIREMENTS FOR THE DEGREE OF

DOCTOR OF PHILOSOPHY

IN

ENGLISH

UNIVERSITY OF RHODE ISLAND

1999 
DOCTOR OF PHILOSOPHY DISSERTATION

OF

HANAN ABDULLATIF

\section{APPROVED:}

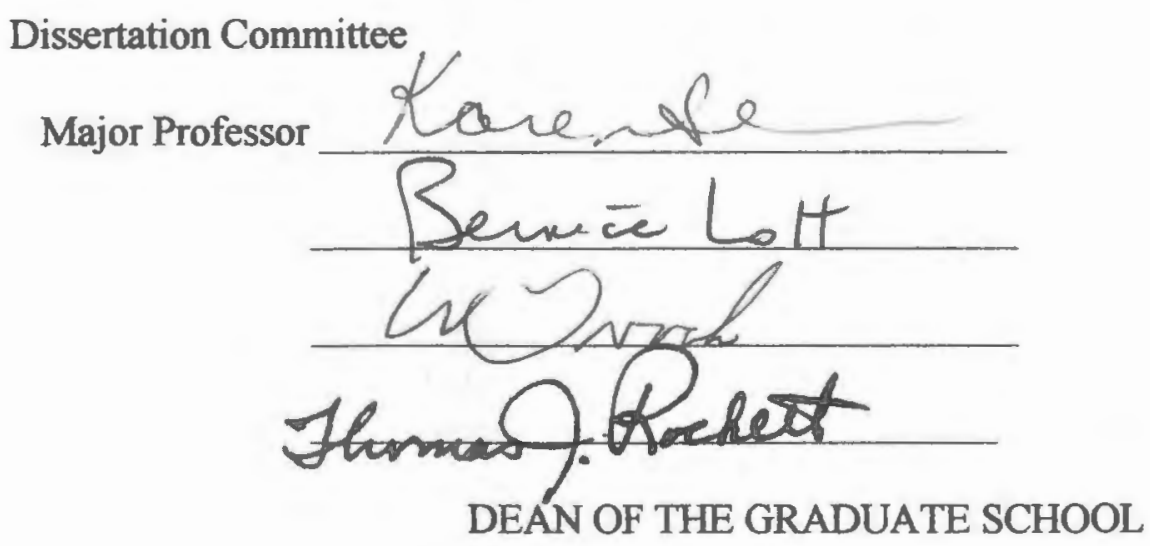

UNIVERSITY OF RHODE ISLAND 


\section{Abstract}

Recovering submerged histories is instrumental in counteracting colonial cultural hegemony and its persistent attempts to erase the past that subject peoples had prior to the epoch of colonial rule. In Toni Morrison's novels reclaiming the past is a necessary condition of subjectivity since it restores a voice and history to those who were deprived of the awareness of both. In other words, it is a restoration of subjectivity. In a postcolonial context, reclaiming the past means more than a linear or literal recording of historical facts. Rather the process of redeeming a past requires that victims of oppression recover their effaced traditions and exhume previously buried communal memories. To enable this process, the oppressed have rallied together and acknowledged their emotional devastation and physical wounds.

Chapter One explicates the importance that Morrison's novels The Bluest Eye

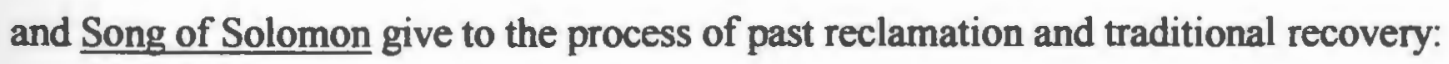
thus, a means of empowering black women against the oppressive institutions of a white culture and its impositions of white images on black girls. Chapter Two analyzes the literary and rhetorical mode in Beloved which defies historical definition, especially when the victims of slavery bind together and excavate memories of colonial oppression. By talking about the past, the oppressed will break the traditions of silence that denied their presence in history. Chapter Three investigates the issues of transitoriness evident in Morrison's novels $\underline{\mathrm{Jazz}}, \underline{\text { Sula }}$ and Tar Baby. In these three narratives, tradition is crucial in overcoming the effects of emotional affliction that resides within travelers who 
leave their old home to settle elsewhere. According to the narratives, to annul the emotional pain that results from leaving one's place of origin, migrants must sustain a fixed sense of identity through their recognition of the traditions and values of the old home. However, to be able to relate to origins, people need not confine themselves to the domain of home. Especially in Sula, Morrison insists that traditions should not fix us to one place. To keep traditions alive, we do not need to adopt the ghetto mentality that confines us to one locale. 


\section{Acknowledgments}

This was hard. I have benefited from my major advisor Doctor Stein's patient guidance, insight and excellent scholarship. My thanks and respect in abundance to my dissertation committee members Profs. Wil Dvorak, Dorothy Donnelly, Bernice Lott and Marie

Schwartz. I appreciate their invaluable comments and ardent encouragement. My appreciation and regard to my friend Lorraina Pinnell who helped me a great deal with her insight and unique approach to literature. My thanks to Bob Pinnell for being a brother to me all through my stay in the United States. My love and appreciation for the Hassans: Joseph, Susan and Dr. Hassan, their loving support made this dissertation both possible and enjoyable. My gratitude to my friend Angel Green who encouraged me to hurry up and finish even though she does not want me to leave the United States. And to my brother Ali: I cannot thank you enough. 


\section{Preface}

This dissertation addresses the importance of Toni Morrison's novels in counteracting postcolonial cultural hegemony, thus, situating her literary corpus within a postmodern literature involving such writers as Alice Walker and Puale Marshall.

Whereas the above writers all share similar concerns, Toni Morriosn, however, is the initiator of the crucial interface between postcolonialism and slavery, a relationship that has not been addressed with similar intensity.

As history tells us, colonialism sustains itself by virtue of the sword and by utilizing forms of mental manipulation. Cultural control consummates itself through the systematic obliteration of local languages and the attempts to efface the historical past and communal traditions of subject peoples. Pretexts such as the "civilizing mission" have are the major tools through which colonialism continues to perpetuate itself. Colonial hegemony imposes a wrap of foreignness on subject people when it insists on their need to conform to a dominant culture. To validate control, colonialism also legitimizes itself through an alleged urge to assist in the economic and social advancement of Other peoples. This form of control employs the masks of the benevolent but 'superior' Other that cares for the welfare of the 'inferior' Others who cannot take care of themselves.

While colonialism is absorbed with its own machinations, it remains oblivious to the fact that the colonized are often cognizant of colonial affectation and persistently attempt to subvert its rule. For example, the colonized have often mastered and 
employed the imposed 'foreign' languages for purposes of 'talking back' to the colonizer. People under colonialism will at times adopt the colonizer's reforming images only as a mask: they use foreign cloaks only to hide their sustained difference from the colonizer.

This dissertation employs a collaboration between Morrison's novels and postcolonial cultural studies. Consequently, the futility of the colonial enterprise, invested in the annihilation of the cultural and physical being of subject peoples, is uncovered. Morrison, of course, recognizes the reality that colonialism has at times succeeded in effecting its control over the colonized. Thus, her novels thoroughly expose the horrendous damage imposed by slavery and other contemporary formseconomic, social, cultural- of repression. 


\section{TABLE OF CONTENTS}

Introduction.

Chapter One: "Of Mimicry and Woman": The Colonial Distortion of Images of the Self in The Bluest Eye and Song of Solomon ................................................... 13

Chapter Two: Resisting the Colonizer's Rhetoric: Beloved .................................... 53

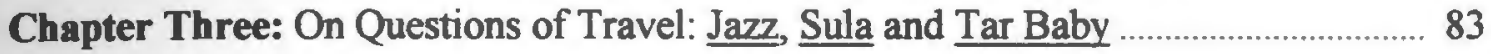

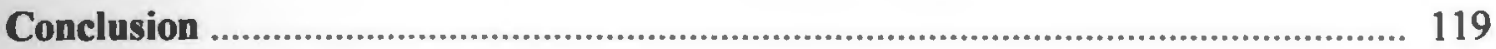

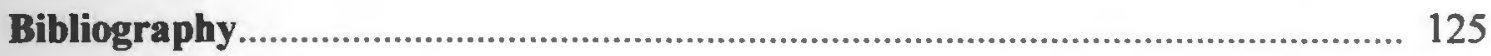


For my mother and father

and the old beloved country 
$\underline{\text { Introduction }}$ 
There are moments when it almost appears as if there is a diabolical continuity (and inevitability?) to it all- that the conduct of the latter-day (internal) slaverunners is merely the stubborn precipitate of yet unexpiated past. The ancient slave stockades do not seem ever to have vanished; they appear more to have expanded, occupying indiscriminate spaces that often appear contingent with national boundaries. Wole Soyinka, The Burden of Memory, the Muse of Forgiveness.

Reclaiming the past from the oppressive history of slavery has been one of the defining features of Toni Morrison's novels. The quest for a cultural identity on the part of the recently emancipated subject has evoked a rewriting of the past and of forgotten communal histories. This reclamation has been achieved through the process of (re)constructing those erased ethnic and cultural traditions. Toni Morrison's novels acknowledge the restorative power of folklore and its importance in counteracting colonial hegemony's cultural denial. Moreover, Morrison's fiction restores a subject position to the victims of slavery by re-animating the voices of the silenced. While postcolonial theory has gone a long way towards addressing the problem of the silenced Other, nonetheless, very little attention has been paid to the postcolonial significance of the American slave narrative. With this in mind, my dissertation analyzes Toni Morrison's novels through the prism of postcolonial and cultural criticism to achieve a two-fold result: a) a richer and fuller elaboration of the novels under question; b) an exposition of the intersecting dynamics of the novel and cultural studies. The study of Morrison's literary work through postcolonial theory has helped me illustrate the text's 
involvement in exposing and subverting the mechanisms through which colonialism continues to perpetuate itself. Edward Said contends that "To have been colonized was a fate with lasting, indeed gotesquely unfair results" ("Anthroplogy" 207). This means that the end of an era of direct colonialism does not necessarily bring about its actual extermination. Thus, Morrison's work critiques the ongoing attempts of white hegemony to impose images of white culture as the universal stereotype-colonialism by any other name.

Morrison's narratives register the historical experience of resistance against slavery, a theme which one finds in the works of novelists as diverse as Alice Walker, Paule Marshall, Renee Green, and Louis Edwards. Like her contemporary AfricanAmerican writers, Morrison exposes the self-asserting and self-deluding mechanisms of racism. Stories included in African -American fiction become methods through which the formerly colonized people assert their identities against colonial hegemony. The stories included in Morrion's texts offer narratives of emancipation that work to enlighten the colonized people against different forms of racist subjection. Beloved, for example, includes the story of the mother who killed her daughter in refusing to give her back to slavery. By reanimating the voices of the silent (the voice of the mother who killed and that of the slaughtered daughter who comes back from the dead to haunt the mother), Morrison leads the reader to relive the past experience of slavery.

Morrison's narratives explore the methods through which the formerly colonized people are still considered inferior and who occupy a less important 
role in the world. A postcolonial mode of analysis is important in illustrating the colonial themes that are dominant in Morrison's novels. The postcolonial form of criticism this dissertation employs is mainly concerned with practices of exploitation and cultural hegemony that define the relationship between the colonizing subject and the colonized. In exploring the history of these practices, postcolonial criticism intersects with cultural studies which start with W. E. B. Du Bois and Sol Plaaje from South Africa. ' Other cultural practitioners who participated in this mode of analysis are C. L. R. James, Frantz Fanon and African critics and writers such as Chinua Achebe, Wole Soyinka and Thiongo Ngugi wa Thiong'o. Moreover, this dissertation includes postcolonial theorists as diverse as Edward Said, Kathryn Trees, Homi K. Bhabha, Patricia Geesey, Salman Rushdie and Renato Rosaldo.

The first chapter of this dissertation is entitled "Of Mimicry and Woman": The Colonial Distortion of Images of the Self in Morrison's Song of Solomon and The Bluest Eye." The first part of the title is borrowed from Homi Bhabha's essay "Of Mimicry and Man." I use "Of Mimicry and Woman" because Morrison's narratives Song of Solomon and The Bluest Eye are particularly keen on exposing white hegemony and its related imposition of white norms on black women. Morrison's two texts are a commentary on the debilitating attempts on the part of black women to assimilate the imposed images of a dominant white culture.

In "Of Mimicry and Man," Bhabha includes a discussion of the British colonial rule in India and the way British colonialism imposed Anglicized and white images on colonial subjects. The British rule over India established itself by virtue of pretexts such 
as the "civilizing mission." One of the purposes of the so-called "civilizing mission" is to impose an outward cloak of foreingnness on Indians. As Bhabha sees it, the colonial discourse has prized itself for transforming the colonized into "a subject of difference that is almost the same, but not quite" (The Location 86). The colonial subject, on the other hand, consciously assumes the "reformed" image as a mask, that is, as a means to retain and hide his/her inward difference from the colonizer. By sustaining an inward difference from the colonizer, the colonized effects a subversion of colonial power and hence manages to defy the scrutinizing gaze of colonialism. While the colonizer intends the imposed image as a discourse which denies the possibility of connection with one's immediate culture, the Indians have adopted the reformed image without disavowing their own cultural values. Rather than passively internalizing the imposed image, the colonized mimics the colonial image and hence goes about wearing it as a mask to hide his/her sustained difference from the colonizer. In this sense, Bhabha's notion of mimicry becomes a subversive practice.

In validating mimicry as a form of resistance, Bhabha does not raise the problem of how and when mimicry ceases to be a disruptive mode. Morrison's narrative draws attention to the ways in which mimicry comprises the danger of internalizing the imposed images of the dominant culture. Song of Solomon and The Bluest Eye confirm Bhabha's notion of mimicry as a subversive strategy, especially when adopted by characters like Pilate Dead and Claudia MacTeer. However, mimicry becomes an oppressive practice, as exemplified in Pecola Breedlove's and Hagar Dead's unrelenting attempts to absorb the imposed images of white culture. Instead of mimicking alien ideologies, Morrison's 
texts suggest an identification with cultural values and a revival of forgotten communal traditions on the part of the colonized. In The Bluest Eye and Tar Baby, the characters will challenge their cultural denial by an open embrace the black culture comprised of black music and the tradition of folk tales, folk songs and shared cultural beliefs. In Song of Solomon, Milkman asserts himself only when he reclaims the past of his family and when he fully understands of the integrity of African-American traditions.

While Milkman casts aside some of the futile values of the upper white culture, Guitar on the other hand replicates those values when he joins the Seven Days, an organization among black people that retaliates the violence perpetrated against them through the arbitrary killing of white people. In this sense, Guitar uses the tools of the oppressor to fight oppression. According to Milkman, Guitar's violent actions do not strike at the heart of the white oppressive power structure.

He tells Guitar, "If they are as bad, as unnatural, as you say, why do you want to be like them? Don't you want to be better than they are" (157). In this instance, Milkman demonstrates the dangers involved in the indiscriminate imitation of colonial violence which is just as futile as the arbitrary killings of blacks by whites. ${ }^{2}$

The second chapter includes a discussion of Beloved and the manner in which the narrative raises the consciousness of the former colonized against the mainstream of the dominant ideologies which give the oppressed no chance to define themselves on their own terms. In Sweet Home Farm the slaves will resist fervently the slaveholder's attempts to define them as subject people. The narrative in Beloved sets the terms for definitions, especially when the slaves insist on telling their own version of history. 
Moreover, recalling the past on the part of the oppressed is likely to disrupt some discourses of history written exclusively from the point of view of the "knowing subject," that is, the male Western master of knowledge. In re-enacting the past, the ex-slaves Sethe and Paul D will unfold the necessary truth about the atrocities of slavery. They also subvert the slaveholder's (Schoolteacher) claim to truth and the discourses that he bases on nature, that is, on watching and analyzing the habits and the physical attributes of the slaves on his farm. Through oral exchange of past stories, Sethe and Paul D reclaim the past and also recover their voice and history.

In exposing the horrendous damages of slavery, Morrison has followed the example of her nineteenth-century literary forebears who affirmed their existence when they wrote autobiographies that register their own experience in slavery. In Beloved, Morrison excels over her literary forebears since she fills in the gaps of the "unspeakable" in the slave narrative. In her essay "Beloved and the Middle Passage: Race, Narrative and the Critic's Essentialism" Molly Abel Travis declares Beloved to be speaking from "the gaps and silences in the slave narratives [resulting] from rhetorical constraints and generic conventions" (181) For example, Sethe, the main character in Beloved, speaks the unspeakable in Harriet Jacobs' Incidents in the Life of a Slave Girl. In order not to win the hostility of her white audience, Harriet Jacobs used the pen name Linda Brent. According to Travis, Harriet Jacobs' narrative imitates the style of the domestic novel: "the primer of ideal womanhood, i.e., chastity along with marital success" (183). This ideal of womanhood has "served as Brent's literary model: her ethical appeal depended on her ability to convince her white readers that she was a chase, 
victimized woman" (Travis 183). Thus, in her quest to imitate the white values of the time, Harriet Jacobs adopts the typical nineteenth-century reticence regarding occurrences of sexual assault the slaveholder Dr. Flint had directed at her. In wearing the masquerade of the femininity ideal, the authors of the slave narrative had to repress part of their anger against the brutalizing system of slavery.

In "The Site of Memory" Toni Morrison discusses the silences existent in slave narratives by virtue of the authors' acceptance of the constraints of the time. She hence critiques the authors' choices to cut the narrative short by using phrases such as, "But let us drop the veil over proceedings too hard to relate" ("The Site" 301). ${ }^{3}$ Rejecting the norms of decorum adopted by her literary forebears, Morrison's new job is "to rip the veil drawn over "proceedings to hard to relate"" ("The Site" 302). In Beloved, Morrison manages to completely disregard the norms of decorum, especially when Sethe writes her anger down to the very end of her narrative. In the same manner as the narratives of Song of Solomon and The Bluest Eye disown the traditions of imitating white values, the narrative of Beloved disclaims the tradition of writing that passively assumed the masquerades of a dominant culture. Thus, Beloved withdraws from the tradition of silence common to some nineteenth-century writing modes and utilizes anger to express the fullness of the devastating effects of slavery.

The Third Chapter discusses themes of travel present in three of Morrison's narratives, namely, $\underline{\mathrm{Jazz}}, \underline{\text { Sula }}$ and Tar Baby. In these three novels, travel is posited as a displacing factor. One form of displacement is physical and points out to the movement of people from one geographical location to another. In $\underline{\mathrm{Jazz}}$, physical displacement is 
epitomized by Joe and Violet's move from the South of The United States to its North. Sula's move to a an unknown metropolitan center defines the physical displacement present in Sula. And in Tar Baby, Jadine's movement to Europe forms the example of physical displacement. I am interested in analyzing the texts' concern with the psychological displacement caused by the physical move. Psychological displacement betides the traveler who attempts to plant him/herself in any new place. In the struggle to be accepted among new people, the traveler adopts the manners and styles of these people. In other words, the traveler would substitute one form of behavior with another. Still figures of travel are psychologically displaced by virtue of the anxiety of becoming a failure in the new place and the fear that they might have lost their homeland forever.

To overcome effects of the emotional displacement the physical move engenders,

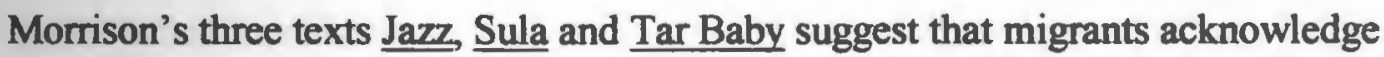
candidly their respective origins and the invaluable communal traditions related to their places of origin. However, Morrison warns against the danger of the nostalgia that befalls the traveler who lives in constant and obsessive recollection of the old home and his/her past in it. Jazz brings up the example of Joe Trace as a reminder of how excessive remembering of the past is likely to predispose migrants to conditions of melancholia. In Sula, Morrison emphasizes the importance of traditions, nevertheless, the narrative insists that traditions should not fix us to one place. Thus, the narrative warns against the adoption of ghetto mentality which confines people to one place or one country. In Tar Baby, the narrative explicates the displacement of Jadine who, by reason of her travels in Europe, has entirely separated herself from the values and traditions of 
the African-American community. Jadine is dislocated because she can not consider herself European, and she can not either be an integral part of the group into which she was born. The three texts stress the importance of communal traditions as instrumental in resisting the emotional displacement accompanying the experience of travel.

Toni Morrison's texts and their inclusion of postcolonial themes are particularly interesting to me since my homeland, Syria, was subject first to Turkish and then the French mandate. It was only in 1945 that the Syrian tenacious Revolution had driven the French colonizing power out of the country. The experience of colonialism is therefore central to our sensibilities and our major education. Our present day society is exemplary for postcolonial conditions similar to the ones Morrison explores in her narratives. In Song of Solomon and The Bluest Eye, Morrison is telling a story that I know and share: the hegemonic infiltration of white values into the black community which The Arab World also partakes due to the penetration of Western ideologies into its values. In our world, evidences of this penetration are discernible in the strife of our people to acquire Western style and in the manner in which members of the upper class society (who sometimes happen to have strong affiliation with the West) embellish Arabic language with foreign words. Beloved exposes the mechanism through which slavery sought to legitimize itself by "classifying" the African race as inferior; colonialism in the Middle East has also attempted to perpetuate itself by categorizing the Arabian race as inferior. Morrison's novels Jazz, Sula and Tar Baby expound upon themes of travel relating exclusively to figures of travel who left their postcolonial homeland to live in some metropolitan sites. The concerns that Morrison raises regarding the travelers' oblivion to 
their home values and traditions are my concerns too, since I left Syria to come and study in the United States. Every time I read Tar Baby, I am overwhelmed with the fear that I too am Jadine who traveled outside her group and forgot her properties. Sula, however, makes me feel optimistic since it brings up issues of hybridity and the needfulness not to be confined to fixed positions. The positive hybrid will inhabit different spaces with a clear sense of his/her past and home values and traditions.

The importance of the intersecting dynamics of Morrison's literary texts and postcolonial cultural studies this dissertation explicates is an ongoing project for the future. The cultural studies of postcolonialism can help illuminate the postcolonial themes present in our rich Arabic literature. This proposed study will also combine the postcolonial themes of Morrison's novels and postcolonial literature from other parts of the world. The next time I write about English, Arabic or any other literature, I am resolved to write in Arabic, my native tongue instead of writing in English, my borrowed language. 


\section{Notes}

${ }^{1}$ For more information on the subject, see Bart Moore-Gilbert 3-4.

${ }^{2}$ Indeed, Guitar's practice is the very notion that Martin Luther King and the Civil Rights Movement challenged.

${ }^{3}$ In her essay “Toni Morrison's Beloved: Re-Membering the Body as Historical Text" Meg Henderson also mentions Morrison's "Site of Memory" to comment on the importance of Beloved to fill the gaps of the silences in the slave narratives. 
"Of Mimicry and Woman": The Colonial Distortion of Images of the of the Self in The Bluest Eye and Song of Solomon 
Riviere's patient, looking out at her male audience, with impropriety, throws back the image of sexuality back to them as "game," as "joke," investing it too with the instability and the emptiness of the masquerade. As long as she is not caught in her own act. As long as she does not forget that the masquerades of femininity and masculinity are not totally unreal or totally a joke but have a social effectivity we can not ignore. We still need to tell our own jokes ... . Mary Ann Doane, "Masquerade Reconsidered: Further Thoughts on the Female Spectatorship"

The purpose of this chapter is to illuminate the way in which Homi Bhabha's postcolonial theorization and Morrison's fiction intersect to expose the mechanisms through which colonialism continues to perpetuate itself. I invoke Bhabha's essay "Of Mimicry and Man" to show how Morrison's fiction replicates issues raised in postcolonial cultural studies. While Bhabha emphasizes the importance of mimicry for subject peoples as a form of resistance against the imposed colonial images, Morrison points to the danger of mimicry and in its place suggests traditions and past reclamation as important tools of self-affirmation and identity recovery.

In his essay "Of Mimicry and Man" Bhabha critiques the imposition of colonial mimicry and its aspiration for an "other" who, while adopting the outward appearance of the colonizer, still retains a difference from "him." According to Bhabha, the colonial discourse prizes itself for transforming the colonized into a "subject of difference that is almost the same, but not quite"(The Location 86). In other words, the so-called civilizing mission is directed by the principle of manners reform, and, therefore, imposes a cloak of foreignness as a masquerade that hides the true attributes of the colonized. The 
colonized subject, on the other hand, consciously accepts the "reformed image" as a construct or rather as an assumable mask adopted only for the "other," that is, the colonized often effects a subversive identity play through false imitation, and often succeeds in evading the scrutinizing gaze of the oppressor. Instead of passively internalizing the imposed "reformed image," the colonized often acquires the image as a mask, assuming thus a role similar to that of the mimic. The colonized subject consciously chooses the mask as a device used to protect the self. On the other hand, when colonial people internalize dominant ideological values, they may succumb to the masquerade and lose their own cultural values as they strive to imitate the "reformed manners" of the colonizer.

Mimicry, according to Bhabha, is a subversive practice. Feminist theory also deals with the subversive mechanism that mimicry embodies. For example, Kimberly Devlin quotes Carol-Ann Tylor who argues that mimicry is "a time-honored tactic among oppressed groups, who often appear to acquiesce in the oppressor's ideas about it, thus producing a double meaning, the same language or act simultaneously confirms the oppressor's stereotypes of the oppressed and offers a dissenting and empowering view for those in the know"(in Devlin: 96). Thus the acquisition of a reformed image could be seen as a "double gesture," since it confirms the colonizer's belief in the validity of the civilizing mission, when in fact it is no more than a simulacrum of acting which offers the colonized alternative identities that question and disrupt the unified message of the colonial discourse. 
In validating mimicry as a form of resistance, Bhabha does not raise the problem of how and when mimicry ceases to be a subversive practice. Feminist critics such as Kimberly Devlin remind us that mimicry comprises the vulnerability of internalizing the masks of the dominant culture. Once this happens, the assumed mask becomes a masquerade and the deliberate simulator unconsciously lapses into passive imitation. The primary difference between the mask and the masquerade consists in the conscious adoption of the mask by subject people in order to effect a strategic but false resemblance to imposed colonial images. However, the significance of the mask as a tool of burlesque can be diffused especially when the mimic mistakes the mask for the true image of the self. With the mimic's fervent attempts to absorb its relative attributes, the mask loses its ironic aspects and becomes a masquerade. While the mask enhances a separation from the dominant culture, the masquerade requires acceptance of dominant values and masquerading subjects would often internalize the adversity of the imitating efforts. Thus, the mask protects the self, but the masquerade harms it.

In two of Toni Morrison novels, Song of Solomon and The Bluest Eye, mimicry is posed as both a subversive strategy, especially when adopted by characters like Pilate and Claudia MacTeer, and an oppressive one, as exemplified in Pecola Breedlove's and Hagar's unrelenting attempts to absorb the imposed images of white culture. The narrative which suggests mimicry as a form of resistance will soon abandon it for identity assertion through open embrace of black cultural values consisting of black music and the tradition of folk tales, folk songs, and shared cultural beliefs. For example, when Milkman finally gets to understand the value and richness of his tradition, he realizes the 
futility of using his father's wealth (an imitation of white social values) as a tool of selfassertion. In Song of Solomon and The Bluest Eye alternative sources of valuation are provided for characters through reclamation and reaffirmation of cultural values the dominant culture has neglected.

In The Bluest Eve, the narrator, Claudia MacTeer, epitomizes Bhabha's conception of a successful mimic, the one who assumes the mask of the dominant culture without absorbing its values. When she reminisces over her former disenchantment with white idols like Shirley Temple, she also imparts her awareness that white beauty does not really exist, that it is valorized, and therefore it exists only through its effects. She even projects her hatred of white idols onto white baby dolls by dismembering them in order to "discover what eluded me: the secret of the magic they weaved on others. What made people look at them and say, "Awwwww', but not for me? The eye slide of black women as they approached them on the street, and the possessive gentleness of their touch as they handled them" (22). Nevertheless, Claudia finally succumbs to society's adoration of white beauty, when she herself develops a liking for Shirley Temple. Ironically, she utilizes her new devotion to expose the mechanism through which the dominant society both directly and indirectly imposes mimicry on black culture. Claudia comments thus, "I learnt much later to worship [Shirley Temple], just as I learnt to delight in cleanliness, knowing, even as 1 learned, that the change was adjustment without improvement"(22). Homi Bhabha might relate Claudia's adjustment to the warfare stratagem of the camouflage: in the same manner as the soldier hides behind a tree which is nonexistent, the mimic seeks false resemblance of the dominant culture. 
Claudia's willful acceptance of white beauty is implicit in her awareness of its "mottled" presence, mottled in the sense that, like camouflage, it takes advantage of absent spaces.

In The Bluest Eye, the narrative covertly points to the presence of a white culture which, like camouflage, sustains itself through what Michelle Wallace deems as "the absence of black images from mass media [as] the crucial dynamic never accounted for" (Out There 40). In mimicking white culture, Claudia is again exploiting the mechanism of the camouflage only to turn it against itself: mimicry in the text effects a "slippery" identity which will assiduously work to deconstruct the white cultural myth. Claudia's acceptance of the Shirley Temples of the world is only a form of accommodation to the dominant view and not an assimilation of it, and, in a sense, she can be a good example of Bhabha's conception of mimicry as "almost the same, but not quite," or, rather, "almost the same but not white"(89).

Significantly, the form of mimicry present in Morrison's text effects a covert disturbance of the binary opposition of black and white. In consciously adopting the mask of whiteness, Claudia becomes more aware of its existence as a valorized social construct. While Claudia's narrative does not in any way advocate any form of beauty based on skin color, it does in a way account for the media's fixation on the domination of women through the myth of whiteness. For example, the secret of the ugliness attributed to girls like Claudia, her sister Frieda, and their friend Pecola Breedlove is to be found in the way advertised images impose hierarchies of beauty. Thus black girls with thinner features and lighter skin color have a better chance of being recognized because they bear resemblance to a prioritized form of white beauty. The encounter with 
mulatto girls becomes another reminder of the racism society initiates. Even for Claudia, the encounter with the lighter-skinned Maureen Peal becomes a source of temporary disequilibrium. The excessive attention the school showers on girls like Maureen Peal is a reminder of the lack of attention that people pay to black girls with darker skin color. Unable to explain the lack of interest society shows for girls like herself, Claudia wonders thus,

If she was cute- and if anything could be believed, she was then we were not. And what did that mean? We were lesser. Nicer, brighter, but still lesser. Dolls we could destroy, but we could not destroy the honey voices of parents and aunts, the obedience in the eyes of our peers, the slippery light in the eyes of our teachers, when they encountered the Maureen Peals of the world. What was the secret? What did we lack? Why was it important? And, so what? Guileless and without vanity, we were still in love with ourselves then. We felt comfortable with our skins, enjoyed the news that our senses released to us, admired our dirt, cultivated our scars, and could not comprehend our unworthiness. Jealousy we understood and thought natural- a desire to have what somebody else had; but envy was a strange new feeling for us. And all the time we knew that Maureen Peal was not the enemy and not worthy of such intense hatred. The Thing to fear was the Thing that made her beautiful, and not us (62).

Claudia here is referring to a society so sickened by the white cultural myth to the extent that it produces a distorted sense of color. Because of their skin tone, black people in the text feel inferior both to whites and to light-skinned blacks. Still, skin color, whether black or white, is not the thing to fear, it is rather the overwhelming hegemony of some cultural ideologies which render people insecure in regard to their physical features. 
The same myth of whiteness which produces insecurity among blacks has also produced Pecola Breedlove, a black little girl who craves whiteness to the extent that, at the end of the narrative, she goes insane with the conviction of having acquired America's bluest eyes. Pecola wants to become white because she is inherently aware of the fact that, in a culture that validates white beauty exclusively, black girls with darker skin color have a very slim chance of being loved. In a tone of desperation, she poses the question of "How do you get somebody to love you"(29), expressing her sadness for not being loved which she also relates to factors of her "ugliness." She even attributes the absence of love between her family members and the constant fights between her parents to inadequacy of her physical features. Pecola's only response to the fierce fighting between her parents, Cholly and Pauline Breedlove, is a prayer she whispers into the palm of her hand of "Please God, ... Please make me disappear" (39). That prayer is so strong that Pecola immediately starts to experience the disintegration of parts of her body, "Little parts of her body faded away. Now slowly, now with a rush. Slowly again. Her fingers went, one by one; then her arms disappeared all the way to the elbow" (39). Pecola's prayer that her body dissolve includes a desire for physical transformation, hence the narrator's comment, "It had occurred to Pecola some long time ago that if her eyes, those eyes that held the pictures, and knew the sights- if those eyes of hers were different, that is to say beautiful, she herself would be different. ... If she looked different, beautiful, maybe Cholly would be different, and Mrs. Breedlove too. Maybe they'd say, 'look at pretty-eyed Pecola. We won't do bad things in front of those pretty eyes"' (40). Pecola's condemnation of her ugliness is gathered through a hostile environment which 
has deemed her ugly. She is ultimately unable to question the validity of the scrutinizing gaze that constantly peers at her. She encounters rejection even within the black community who project onto her their own "learned" (55) self-hatred. To the white people of the community, Pecola, like other non-whites, does not even exist, and every encounter with whiteness confirms her sense of invisibility. When she goes to buy her favorite candies at the shop of white immigrant storekeeper, she encounters silent rejection from him:

She looks up to him and sees the vacuum where curiosity ought to lodge. And something more. The total absence of human recognition- the glazed separateness. She does not know what keeps his glance suspended. Perhaps because he is grown, and a man, and she a little girl. But she has seen interest, disgust, even anger in grown male eyes. Yet this vacuum is not new to her. It has an edge; somewhere in the little lid is the distaste. She has seen it lurking in the eyes of all white people. So. The distaste must be for her, her blackness. All things in here are flux and anticipation. But her blackness is static and dread. And it is the blackness that accounts for, that creates, the vacuum edge in the eyes with distaste in white eyes (42).

This instance depicts the complicity of the dominant society in enforcing Pecola's negative perception of herself. In the face of such overwhelming negation, Pecola becomes unable to communicate verbally with the storekeeper. Instead, she uses her finger to point out her favorite candy, Mary Jane. That Pecola has internalized the distaste cast upon her by the above (master)narrative is reflected both in her silence and in her adoration of white idols. Her discontent at the storekeeper's indifference is soon 
forgotten when Pecola gets hold of the three candies named after Mary Jane. In eating the candy, Pecola tries to assimilate into the image of Mary Jane. The narrator explains, "She eats the candy, and its sweetness is good. To eat the candy is somehow to eat the eyes. Eat Mary Jane. Love Mary Jane. Be Mary Jane" (43). Pecola’s unquestioned acceptance of the idealization of white beauty is symptomatic of self-abnegation. When she drinks milk out of a Shirley Temple cup, Pecola is unconsciously negating her blackness and trying to take on the mask of the dominant culture.

In Morrison's narrative, whiteness becomes a form of femininity or commodity construct that black girls are made to submit to. In her essay "The Bluest Eye: Notes on History, community, and Black Female Subjectivity" Jane Kuenz observes that "femininity and the 'sexual' can be produced and reproduced as commodities, as Pecola's belief that she can simply acquire blue eyes indicates. The mass dissemination of these images of femininity in American society was and still is among the primary mechanisms by which women are socialized and sexualized in this country" (Kuenz 424). Nonetheless, femininity has often had sickening effects on women who absorb its mechanisms. Pecola's taking on the mask of the white feminine is no longer an act of mimicry. It is an attempt to assimilate the mask of the dominant culture into an image of the self. Thus, the mask that she has taken on becomes a masquerade, since she seeks emblems of white beauty such as blue eyes as alternative to her real life. Pecola pursues whiteness in order to make accommodation with the world. Still she acquires white beauty only in a distorted form, and towards the end of the narrative we hear her converse with an imaginary "friend" about the splendor of the "bluest eyes" she alone has 
been endowed with. In a sense, Pecola's madness forms a good example of women's predicament Juliet Mitchell's describes showing how internalized norms of dominant culture are likely to produce cases of hysteria. Whiteness as a form of femininity can also become an internalized norm, and, as Mitchell might see it, whiteness is "in part a repressed condition that can only be secondarily acquired in a distorted form. It is because it is repressed that femininity is so hard to comprehend both within and without psychoanalytic investigation- it returns in symptoms such as hysteria" (Psychoanalysis, 404). ${ }^{1}$ Pecola's lunacy towards the end the narrative confirms Mitchell's argument of how the return of the repressed always proves costly. In the narrative, Pecola's hysteria is brought about by her inherent awareness of her blackness as inferior to the femininity represented in white beauty. The impossibility of her ever acquiring whiteness is the repressed element. With society's constant aggravation, Pecola's repressed desire leads to the illusory conviction that she has really acquired whiteness and hence her madness is derived through the conviction that hers are the bluest eyes.

The narrative of The Bluest Eye is insistent in exposing society's responsibility for creating mad girls like Pecola. Pecola's aspiration for physical transformation stems from the need to be accepted in an environment which is particularly hostile to black girls whose features do not "measure up." Because of the way she looks, Pecola occupies the position of the guilty and the silent. To her mother, Pauline Breedlove, Pecola is no more than a reminder of her own failed aspiration to acquire white beauty. Pauline herself tried to acquire the masquerade of white femininity she sees at the picture show, complying thus with Hollywood's traditions of idealizing white beauty. The 
narrative is particularly critical of certain aspects of movies produced during the 1930s, the era in which Morrison's text is situated. What the screen represents covertly enhances Pauline's ultimate dissatisfaction with her self and with what she has. In portraying Pauline as utterly infatuated with the subversive ideologies of cinematic representation, Morrison might also be critical of what Laura Mulvey deems as the "tendency of film to absorb the spectator into itself"(Visual 156). Pauline herself admits that

The onliest time I be happy seem like when I was in the picture show. Every time I got, I went. I'd go early before the show started. They'd cut off the lights and everything be black. Then the screen'd light up, and I'd move right on in them pictures. White men taking such care of they women, and they all dressed up in big clean houses with the bathtubs right in the same room in the toilet. Them pictures gave me a lot of pleasure, but it made coming home hard, and looking at Cholly hard. I don't know. I remember one time I went to see Clark Gable and Jean Harlowe. I fixed my hair up like I'd seen her in magazine. A part on the side, with one little curl on my forehead. I looked just like her. Well, almost just like her (97).

Lacking the strength to resist idealized images on the screen, Pauline attempts to masquerade as a white idol. Nevertheless, she fails to identify herself as Jean Harlow when, due to pregnancy, she loses a front tooth. Her hopes then of acquiring attributes of white beauty are shattered. She asserts, "There I was, five months pregnant, trying to look like Jean Harlow, and a front tooth gone. Everything went then. Look like I didn't care no more"(98). Moreover, Pauline brings up the sadness of feminine identification when she turns to her unborn child for the fulfillment of her dream, hence making Pecola 
the signifier of her own desire to become white. When Pecola disappoints her mother's wish for a white-like child, Pauline's implicit response was to abandon her child, or rather, both her children, for the blond girl of her employers. Unquestionably, Pauline is infected by the racism which has also contaminated the life of many black people, and this is implicit in the way she negates her children because she perceives them as ugly. When Pecola is born, Pauline fails to see her other than "Head full of hair, but Lord, she was ugly" (100). Pauline has been both mentally colonized by the rhetoric of the dominant culture and morally deprived by it. The narrator observes, "In equating physical beauty with virtue, she stripped her mind, bound it, and collected self-contempt by the heap" (97).

Because Pauline is unable to view herself on equal terms with her white neighbors, she also takes to masquerading. Especially when she ponders on her husband's drunkenness, she postulates herself as victim and she elaborates on Christianity as her only source of endurance. Pauline's religious stature is another form of white masquerade. The narrator tells us that she "joined a church where shouting was frowned upon"(100). Christianity in the case of Pauline is an evidence of grotesque imitation of white values. Still her religious masquerade will serve to further confirm Cholly's banishment from her life and from her love which he mostly needs.

Cholly's abandonment by his wife is not an isolated incident, but rather reinforces an extended pattern of treatment Cholly has been subjected to since infancy. The narrative depicts Cholly's victimhood as a result of parental abandonment, economic deprivation and racial degradation. When Cholly was only four days old, his mother 
abandoned him in a junk heap on the railroad; his great aunt rescued him and has since persistently reminded him of his indebtedness to her. His long search for his father becomes a source of disappointment, especially when his father rejects him for a crap game. Moreover, his first real exposure to white hegemony took place while Cholly was having his first sexual encounter with a girl named Darlene. A few white men happened to arrive on the scene and they intimidated Cholly even more when they demanded that he resume the act their arrival had interrupted. The sarcasm of their tone, their overpowering presence and the their openly racist remarks rendered Cholly impotent. Not being able to retaliate against the white intruders, Cholly cultivated his anger against Darlene who was as much a victim in this as Cholly ever was. The incident makes Cholly aware of his helplessness in the face of an overwhelmingly hostile white world that emasculates him both physically and emotionally. The narrator states, "They were big, white, armed men. He was small, black, helpless. His subconscious knew what his conscious mind did not guess- that hating them would have consumed him, burned him up like a piece of flash coal" (119). Therefore, Cholly projects his hatred on Darlene as the one who "bore witness to his failure, his impotence. The one whom he had not been able to protect, to spare, to cover from the round moon glow of the flashlight"(119). The question that presents itself here is whether Cholly will ever be able to protect the people he would truly love if only he knew what love is. Would Cholly be able to wash away Pecola's misery which he suddenly becomes aware of? To ask the question differently, would Pecola's misery not remind him of his own, and does her misery not stem from the same source, that is, Pauline's cultivated preferences ending in ruthless separation from 
every member of her family. Unquestionably, Cholly's victimhood position reflects on his incapacity to approach his daughter's grief without further victimizing her. The narrator, for example, comments,

What could a burned-out black man say to the hunched back of his daughter? If he looked into her face, he would see those haunted, loving eyes. The hauntedness would irritate him, the love would move him to fury. How dare she love him? Hadn't she any sense at all? What was he supposed to do about that? Retum it? How? What could his calloused hands produce to make her smile (127).

Cholly can love Pecola only in the same manner as he loved her mother, that is, by surrendering the emotional to the realm of the physical. When Pecola inadvertently "shifted her weight and stood on one foot scratching the back of her calf with her toe"(127), Cholly could only relate the gesture to what Pauline was doing when they first met. And, even though it was a small and simple gesture, still

it filled him then with a wondering softness. Not the usual lust to part tight legs with his own, but a tenderness, a protectiveness. A desire to cover her foot with his hand and gently nibble away the itch from the calf with his teeth. He did it then, and started Pauline into laughter. He did it now (128).

The awakened attachment towards his daughter acts also as a reminder of his love for Pecola's mother, probably of his desire to break Pauline's pride. Still Cholly's tenderness proves disastrous, especially when it ends up in rape. Thus, Pecola's wish to be loved was never realized, since the only person who loved her has also victimized her.

Pecola's hysteria towards the end of the narrative is a response to rape and to the constraints of society. Her conviction that she has acquired blue eyes might epitomize 
Bhabha's definition of the mimic as a figure that "thrives to be culturally 'seen.' What [she] aspires for is visual mediation"(The Location 85). However, Pecola, together with her mother, has absorbed the mask of the dominant culture in her struggle to be culturally recognized, and her mimicry is self-destructive rather than productive. Pecola as a mimic deconstructs Bhabha's notions of mimicry as a subversive practice.

As a more successful strategy than mimicking or emulating aspects of the dominant culture, the Bluest Eye suggests alternatives to the ideologies of whiteness through the presence of African American music and a carnivalesque embrace of life. In "Carnival and Black American Music as Counterculture in Toni Morrison's the Bluest Eye and Jazz, "Inger-Anne Softing explains that both carnival and Black American music are counter expressions to Western expressive forms through their "concern with openings, ambiguities and plurality"("Carnival" 82). Typical features of carnival are the "low, the grotesque and the excessive; in short the 'unspeakable' official aspect of the world" ("Carnival" 82). Black music, on the other hand, combines the experience of the plurality of living situations. The blues song are indicative of carnival ambivalence especially in what Softing contends as the "ambivalent relationship of the blues to the sweet and bitter"(91). The blues of Mrs. MacTeer, Claudia's mother, combine this carnival ambivalence since they use the painful as well as the sweet to create the love of life and the means of surviving its misfortunes with fortitude and without falling into indisposition and death. Claudia asserts,

If my mother was in a singing mood, it wasn't so bad. She would sing about hard time, bad time, and somebody-done-gone-and-left-me times. But her voice was so sweet and her singing-eyes so melty, I found myself longing for those hard times, 
yearning to be grown without a 'thin di-ime to my name.' ... Misery colored by the greens and blues in my mother's voice and took all the grief out of the words and left me with the conviction that pain was not only endurable, it was sweet (24).

Mrs. MacTeer's blues grasp anew the presence of a "subculture" which has been neglected by the dominant one. Present in Mrs. MacTeer's songs are the authentic experiences of the Mac'Teers or the Breedloves which we might also bring up in contrast to the superficial perfection of the white world as presented in the movies. Rather than elevating above common occurrences, the blues embrace the authenticity of the experience of living in its diverse forms. From her mother's songs, Claudia learns not to value certain artificial items of ownership. Instead, she trains herself to sensually experience her surroundings and to derive pleasure from that. She tells us,

Had any adult with the power to fulfill my desires taken me seriously and asked me what I wanted, they'd have known that I did not want to have anything to own, or to possess any object. I wanted rather to feel something on Christmas day. The real question would have been, "Dear Claudia, what experience would you like on Christmas?" I could have spoken up, "I wanted to sit on the low stool in Big Mama's kitchen with my lap full of lilacs and listen to Big Papa play his violin for me alone." The lowness of the stool made for my body, the security and warmth of Big Mama's kitchen, the smell of the lilacs, the sound of the music, and, since it would be good to have all of my senses engaged, the taste of a peach, perhaps, afterward (21).

In contrast to Pauline, Claudia asserts her own identity by embracing an experience quite alien to the one the dominant society imposes. She supports a kind of pleasure that 
derives from uncommodified items such as peaches and lilacs. In The Bluest Eye, food is more than a need for bodily survival and it is more than a tasteful enjoyment, it is rather a source of erotic pleasure which is often associated with female sexuality. In "Rainbows and Brown Sugar: Desire and the Erotic" Barbara Rigney reminds us that "in Morrison's texts, food, like everything else in her worlds, is metaphoric, diffusely erotic, expressive of jouissance"(The Voices 81). For example, Cholly will never forget the pleasure that he once obtained from sharing a watermelon with a group of men. The narrative offers an elaborate comment on both the juicy richness of the watermelon and the pleasures it has afforded the men:

Blue jumped. 'Aw- awww,' he moaned, 'der go da heart." his voice was both sad and pleased. Everybody looked to see the big red chunk from the very center of the melon, free of rind sparse of seed which had rolled a little distance from Blue's feet. He stooped to pick it up. Blood red, its planes dull and blunted with sweetness, its edges rigid with juice. Too obvious, almost obscene in the joy it promises (107).

The watermelon promises the men the enjoyment beyond the senses of the taste. It is suggestive of sexual pleasure, or, as Rigney suggests, it is associated with Jouissance, a metaphor of love, and an "emblem of female sexuality"(The Voices 83).

Implicit in the narrative of The Bluest Eye is also the critique of the alienation from the sensual pleasure which often accompanies the attempt to absorb the masquerades of the dominant society. This is obvious in the girls from Mobile and Aiken whose lives border on the desire to learn "how to behave"(68). These girls, the narrative tells us, "do not drink, smoke, or swear, and they still call sex 'nookey"” (68). In their 
strife over the acquisition of what Bhabha observes as "refined manners," these girls have repressed all forms of physical and natural pleasures: "Whenever it erupts, this Funk, they wipe it away; where it crusts, they dissolve it, wherever it drips, flowers, or clings, they find it and fight it until it dies. They fight this battle all the way to the grave" (68). The diligent obliteration of the physical and the natural is indicative of alienation from the self, the body and from one's own culture. The "Funk" is an important feature of black culture, because it valorizes natural and bodily pleasures in opposition to the bourgeois tendency towards avoiding, if possible, that which it considers natural. Inger-Anne Softing provides an illustration of the sexual connotation of the "funk" as well as its occurrence in black music as a counter text to the white bourgeois ideology: "in the black ghettoes in America [the 'Funk'] was also given clear sexual connotations; it referred to the smell of sexual excitement and in particular it referred to the female sex. The musical expression called funk has preserved these overt connotations to sex and other 'unspeakable' issues. Through its provoking directness it communicates an explicit defiance of bourgeois codes ("Carnival" 85 ).

In a sense, the funk could be viewed in opposition to society's demand for a "reformed image." Another dominant feature of Morrison's text is a carnivalesque sense of the world which also strongly reverses the codes of the dominant culture. The narrative's inclusion of the prostitutes China, Poland and Marie, known as Maginot Line, introduce the reader to their own carnival style of living. The women's freedom from all forms of social restrictions stands in sharp contrast to both Pecola's blind acceptance of white ideologies and Claudia's adjusting mimicry of their images. Their style of living 
offers the chance for laughter and embraces generously various forms of the grotesque. Softing argues convincingly that laughter and the grotesque "are closely connected in camival, and laughter is one of the fundamental components of carnivalized literature. The carnival laughter is nonauthoritarian and nonhierarchical; nothing is exempted from ridicule and everyone can laugh at anything "("Camival" 87-8).

Morrison's narrative is compatible with Softing's insight into the liberating effects of carnival laughter. Especially in the part that deals with the three prostitutes, laughter is posed as an indispensable liberating power, since it affects a break from official "norms." Marie, for example, tells a story about the first time she was given a pair of drawers which she mistook for some kind of "stocking cap" (46) and wore them on her head while dusting. In defending herself, she states, "And what's the use of putting on something you got to keep taking off all the time?" (46). The anecdote includes an element of mirth which subtly affects a carnivalesque disturbance of the values society attributes to items of clothing. Moreover, Marie's displacing of items of clothing suggests carnival reversal of the formal image society imposes and it also counters the demand for "refined manners." Carnival is also implicit in Marie's willingness to present herself as a clown dressed up in drawers and to share her companions' laughter at her ignorance about modes of clothing. Their laughter points out the carnival element of Marie's story, and laughter, as Renate Luchmann explains, "enables the carnival to take place ("Bakhtin" 123). According to Renate Luchmann, camival and laughter are interrelated because "laughter rises above and transcends the 
objects at which it is temporarily aimed: official institutions and the sacral" ("Bhaktin" 123).

The Maginot Line will exempt nothing and no one from their laughter and ridicule. They primarily direct their laughter at themselves, especially when they recognize the grotesque features of their bodies. In camival, the grotesque body is perceived as disproportionate and excessive. Important to this present concern is Renate Luchmann's definition of the grotesque body as becoming "the stage for eccentricity. It is the body that transgresses its own boundaries, that plays up its own exaggeration: the grotesque body"("Bakhtin" 146). In The Bluest Eye the carnival image of the body is represented in Marie's body and its manifestations of the categories of the grotesque. The text comments thus,

A mountain of flesh, she lay rather than sat rocking chair. She had no shoes on, and each foot was poked between the railings: tiny baby toes at the tip of puffey feet; swollen ankles smoothened and tightened the skin; massive legs like tree stumps parted wide at the knees, over which spread two roads of soft flabby inner thigh that kissed each other deep in the shade of her dress and closed. A darkbrown root-beer bottle, like a burned limb, grew out of her dimpled hand. She looked at us through the railings and omitted a low, long belch (82).

In its massiveness, Marie's body transgresses the boundaries society sets for the "functional" body. The grotesque body covertly illustrates Mary's liberation from the "quotas" that women are made to fulfill. Because the three of them have not been entrenched in institutional hierarchies, they would not notice that Pecola's blackness is different from anybody else's, and, besides Claudia and Frieda, they are the only people 
in the community who befriend Pecola. Likewise, Pecola has accepted the three women for the way they are, and has acknowledged her friendship with them by refusing the derogatory naming the "Maginot Line" the community has assigned them. Instead, she reverently refers to each one of them by her first name preceded with "Miss."

Because she has been blinded by the overwhelming presence of a white ideology, Pecola fails to learn from her friends the methods of the ongoing psychological battle each one of them, including Claudia, has to fight against the mechanisms of an alien culture. Once she takes to imitating the values of the dominant society, Pecola becomes both a stranger both to herself and to the society she is trying to emulate. Pecola's case could be inserted into Bhabha's argument as an example of how and when mimicry ceases to be a subversive strategy and becomes destructive to the mimic.

On the other hand, Song of Solomon does incorporate mimicry as a subversive practice. The narrative deals with the occasional validity of colonial mimicry especially when Pilate Dead plays the mimic at the police headquarters in an attempt to impress the officers into releasing her nephew Milkman and his friend Guitar Bains. Milkman was led by his father, Macon Dead, to believe that the sack Pilate has been keeping for years as her alleged "heritage" contains the gold she stole from her brother a long time ago. Accompanied by his friend Guitar, Milkman breaks into Pilate's house to steal the sack which, after all, contained no more than a dead man's bones. At the police station, the long and stoutly built Pilate astonishes Milkman by looking shaky and short. Milkman will later reminisce on how Pilate "had been shorter. As she stood there in the receiving room of the jail, she didn't even come up to the sergeant's shoulder- and the sergeant's 
head barely reached Milkman's own chin. But Pilate was as tall as [Milkman] was" (206).

Pilate also offers false justification for the possession of a dead man's bones. She claims that the bones belong to her late husband who had been lynched in Mississippi and whose remains she has so far kept because she did not have the money to pay the “sfuneral peoples"' (207). While watching Pilate, Milkman is bewildered by the skillful identity play she performs, and his amazement reaches its peak when Pilate quotes from the Bible: "Bible say what so e'er the Lord hath brought together, let no man put asunderMatthew Twenty-one: Two. We was bony fide and legal wed, suh" (207). Pilate's citation of the Bible by chapter and verse disconcerts Milkman who previously believed that her knowledge of the Bible is as limited as his own. Pilate's use of the Good Book is a burlesque, a joke, at the expense of the police. The sergeant who does not know Pilate takes her story seriously and dismisses the case. He has not seen through Pilate's performance because her pleading is accompanied by a gestural transformation: "her eyes, those big sleepy old eyes, were small as she went on: 'so I thought I just as well keep him near me and when I die they can put him in the same hole as me. We'll raise up to the Judgment Day together. Hand in hand"' (207). It is clear in this instance that Pilate is invoking a religious text for political and practical purposes. It is an obvious act of subversion. Pilate's invocation provides a loophole from the severity of the Law. Likewise, her image of smallness is an assumed mask of inferiority worn in order to placate the policeman . Her mimicry as a subversive strategy is successful as she manages not only to redeem her sack but also to free both Milkman and Guitar from 
imminent imprisonment. Once she leaves the police department, Pilate's mimicry is over, and Milkman observes how she "was tall again. The top of her head, wrapped in a silk rag, almost touched the roof of the car" (207).

Pilate's mimicking action is a separate incident and not a pattern of behavior. Her mimicking performance contradicts her major portrayal in the narrative as a "woman who looked as though she might move the earth if she wanted to" (6). Nowhere in the narrative does Pilate attempt to emulate the values of the dominant culture. Even as a young girl, she has expressed her independence from the norms of beauty society creates by cutting her hair very short. What mostly attracts the attention of the reader about Pilate is her poorly dressed appearance which signals a freedom from fashion and other forms of cultural "packages." For example, Pilate's items of clothing include a "knitted navy cap pulled far down over her forehead" (5), also an "old quilt" she uses for a coat, and masculine boots she keeps unlaced (6). To her only brother, Macon Dead, Pilate's raggedy style is a source of embarrassment (20).

What mostly shames Macon Dead is his sister's disregard of social proprieties. For him, freedom and ownership are tied in together. He tells his son Milkman, "Own things. And let the things you own other things. Then you will own yourself and other people too" (20). Macon Dead seeks to liberate himself through ownership and appropriation, but he remains a slave to the dominant ideology which rears the notion of ownership. In this sense, Macon acquires what Morrison deems as the "parasitical nature of white freedom" (Playing 57). In the narrative, Macon becomes the epitome of Anaanu in West African folk tale. As Barbara Rigeny argues, Anaanu is a "trickster spider who 
escapes famine by faking death and at night he kills his fill: Macon, like Anaanu, chooses dispossession in order to achieve material gain" (The Voices, 66). While informing his son about their family history, Macon poses himself as the victim of having witnessed the gruesome killing of his father by some white people who wanted to usurp the late Macon Dead's farm. Macon Dead's father preferred to die rather that give up the land he cut from the woods and painstakingly cultivated. While waiting for the white aggressive neighbors who wanted his land, Macon Dead was shot in the back. According to Pilate, "They blew him five feet up into the air. He was sitting on his fence waiting for 'em, and they snuck up from behind and blew him five feet in the air" (40). While his father was a real victim of white oppression, Macon Dead has assumed victimhood in order to justify his obsession with money and ownership. Pilate has also witnessed the ruthless killing of her father, but she confronts brutality with the opposite act of loving, healing and nurturing. To her neighbors, she is known as a "natural healer, and among quarreling drunks and fighting women she could hold her own, and sometimes mediated a peace that lasted a good bit longer than it should have because it was administered by someone not like them" (150). This directly fits into Wedretz-Furtado's accurate observation that Pilate, through her "Willpower" has demonstrated that "history need not be fate. She is the illustration of the opening statement of one of Toni Morrison's lectures: “'that bestial treatment of human beings never produces a race of beasts"' ( Historical 230).

What also differentiates Pilate from her brother is her indifference to all forms of ownership. While Macon Dead is known as the most propertied "colored" in town (the 
famous practitioner who lives in a big house on Not Doctor Street), Pilate lives in a poor neighborhood known as South Side in a house with no electricity because she does not want to pay for the service, no gas and with no phone utilities (27). Despite the poverty of Pilate's household, the "fruity" smell of the house and its location in the midst of four huge pine trees has given it the feel of "haven" and a "safe harbor." To Macon Dead, the pine trees surrounding her house are a reminder of Pilate's mouth, of how "she loved, as a girl, to chew pine needles and as a result smelt even then like a forest" (27). Because of her attachment to the guts of the earth, Pilate has taken to making and selling wine as a means of living. She also excels in preparing "runny eggs," and Milkman will remember for the rest of his life the first egg Pilate gave him. She tells Milkman, "I don't like my whites to move, you know. The yoke I want soft, but not runny. Want it like wet velvet"(39). Pilate's embrace of what is natural stands in sharp contrast to society's predominant preference for commodity products.

Moreover, Pilate's capacity at utilizing natural items manifests her skills as an herbalist. According to Ruth Foster, Macon Dead's wife, Pilate has had a vital role in Milkman's birth. At Ruth's request, Pilate gave her "grassy-looking stuff" (125) to put in Macon's food. Pilate's herb temporarily renewed Macon's interest in his wife and their short-term sexual intimacy ended up in Ruth's conceiving Milkman. Later, when Macon found out about his wife's pregnancy, he suspected the role Pilate had in it and he ordered his wife to abort the baby. This time Pilate uses magic to stand off her brother, and, years later, Ruth learns that Pilate managed to abate her brother's anger by smuggling into his office a male doll with a small "painted chicken bone stuck between 
its legs and a round red circle painted on its belly. Frightened by this image, Macon knocked it out of the chair and with a yard stick pushed it into the bathroom, where he doused it with alcohol and burned it. It took nine separate burnings before the fire got down to the straw and cotton ticking of its insides" (132). This incident demonstrates Pilate's intimate acquaintance with African-American tradition and its embodiment of magic. Through her capacity to utilize magical practices, Pilate has also disrupted the male authority over the female. Despite Macon Dead's vengeful and physical attacks against the baby and its mother, Milkman's birth becomes real because Pilate has willed it. Later in life Milkman's growth of character will be a result of grasping the importance of the traditions Pilate introduces to him. Not before he digs deep into the roots of a folk song that Pilate has continually sung will Milkman be able to attain maturity and appreciation for those who love him the most. Pilate sings thus,

O Sugarman don't leave me here

Cotton balls to choke me

O Sugarman don't leave me here

Buckra's arms to yoke me. ...

Sugarman done fly away

Sugarman done gone

Sugarman cut across the sky

Sugarman gone home

From this song Milkman will learn the history of his family which is also the history of his own race and their unyielding aspiration for mythical flight back to Africa as a way 
out of oppression. Further on more will be said about the cultural significance of the song and its impact on Milkman's inner growth.

Unlike Milkman, Hagar, Pilate's only granddaughter, has failed to follow in her grandmother's footsteps in breaking the bonds of the dominant society and therefore becomes victim of her unquestioned acceptance of its values. Like Pecola of The Bluest Eye, Hagar also attempts to hide behind a borrowed image that does not belong to her. Because of her infatuation with white beauty, she becomes convinced that Milkman has rejected her for reasons of her blackness. Upon seeing Milkman with a silky-haired and gray-eyed girl (127), Hagar becomes firmly convinced that she lacks physical beauty.

Even when Pilate holds a mirror up to Hagar's face in an attempt to make her recognize her beauty, Hagar's response is "Look at how I look. I look awful. No wonder he didn't want me. I look terrible" (307). What she sees in the mirror is a reflection of the prejudice society holds against black girls. In "Hagar's Mirror: Self and Identity" Barbara Rigney contends that "The mirror lies in telling [Hagar] that she is not beautiful, for mirrors represent white standards of beauty" (The Voices 35). Rigney's observation signals the importance of social constructions in shaping women's perception of themselves. Thus Hagar's perception of her face as "awful" reflects her debilitating awareness of the scrutinizing gaze of her racist and sexist surroundings. Hagar fears that unless she possesses the characteristics of beauty the dominant culture assigns to women, she has a very slim chance of being loved. What she perceives as her degraded status, she also seeks to eliminate by imitating white values and standards. 
The urge to win back Milkman by acquiring white beauty forces Hagar out of her sick bed. She deprives Pilate and her mother Reba of their last penny for the purpose of shopping for beauty bars, perfumes, and new clothes. The desire to acquire the commodities the dominant society propagandizes is significant of the struggle to obtain a "reformed image." Hagar's sudden infection with the mania to shop for the commodities designed to lighten darker skin and the yearning for straight hair are suggestive of her desire to cover up her physical features and substitute for European ones. She seeks elevation through the borrowed masquerade of whiteness. Like Pecola, Hagar has also internalized the mask of the dominant culture: she wants to be something other than herself, and, as Softing comments, she too "literally goes shopping for a new self- a self which cannot be her" (87). Like her stripped selfhood, Hagar's newly acquired items are shattered when the rain causes a split in her shopping bags. On her death bed, Hagar wants to know, "Why don't he [Milkman] like my hair?"(315). She is convinced that Milkman "likes silky hair" (315). Pilate answers: "How can he not love your hair? It's the same hair that grows out of his armpits ... It's his hair too. He got to love it"(315). In vain, Pilate tries to make her granddaughter look into the truth of her own equality to Milkman who is also a bearer of African features. Being a man does not give him the right to reject in Hagar the physical traits he shares with her. Hagar, nevertheless, is heedless of Pilate's significant lesson, and, even at her death, she remains convinced that Milkman likes silky hair and "gray-blue eyes" (316).

Both Pecola and Hagar are victims of an alien culture that would not accept them for the way they are. Not having the inner strength to counter negation, they internalize 
the inferior status assigned to them. Central to our present concern is Fanon's argument in "Racism and Culture" that

The inferiorized group had admitted that, since the force of reasoning was implacable, that its misfortunes resulted directly from its racial and cultural characteristics. Guilt and inferiority are the usual consequences of this dialectic. The oppressed then tries to escape these, on the one hand by proclaiming his total and unconditional adoption of the new cultural models, and on the other, by pronouncing irreversible condemnation of his own cultural style ("Racism" 38-9).

Hagar and Pecola are examples of the inferiorized group Frantz Fanon is discussing here. Especially when they attempt to efface traces of their culture and race through the diligent adoption of new cultural models, they unconsciously affirm their submission to the belittling mechanisms of the hierarchical society.

Hagar's psychological enslavement brings about her death. Unlike Pecola and Hagar, Milkman overcomes his psychological ailment when he discovers a way out of his alienation from his own culture. Before his trip to the South, Milkman has been convinced that he can attain freedom only through ownership. He therefore initiates a trip to the South in search of the gold which, according to his father, is to be found in a cave close to where their old farm used to be located. After the murder of their father, Macon and Pilate were taken into hiding by Circe, the midwife who ran the household of the same people who killed Macon Dead. Upon leaving Circe, the young Macon and Pilate took refuge in a cave where they found a sack of gold which belonged to a white man Macon had earlier killed in self-defense. Pilate prevented her brother from taking the gold and Macon believed that she had kept it for herself. When Milkman tells his 
father about a sack he has seen hanging from Pilate's ceiling and to which Hagar refers as Pilate's “inheritance," Macon's suspicions of Pilate's past betrayal are confirmed. However, to Macon's great surprise, the sack later proves to contain no more than the bones of the man he killed in the cave. Pilate has kept the bones all these years because her father's ghost had once instructed her that "You just can't fly on off and leave a body" (208). Based on Pilate's story, Macon Dead becomes convinced that the gold is still in the cave were they left it, and hence he sends Milkman on a trip to the South in search of it.

Once in the South, Milkman's interest in finding the gold diminishes as he becomes more interested in gathering information about his family history. What evokes his curiosity as to the past of his family is the living memory friends have kept in regard to his grandfather Macon Dead. Milkman also meets Circe, the old midwife who helped deliver his father and Pilate, and from her he learns that the real name of his grandfather was Jake and not Macon Dead. When he first meets Circe, Milkman is frightened by her resemblance to the image of the witch in the fairy tales. Later on she strikes him as a healer and a nurturer, as someone who "would have been the head nurse at Mercy" (246). She tells Milkman of the drunken Yankee who gave his grandfather the name Macon Dead which the latter did not correct because he could not read. Even after slavery, the naming of blacks is a residue of their ownership, and only those with power can name, therefore it is a trace of past ownership which permanently refers back to the history of slavery. Illiteracy, as a further trace of the educational oppression of slavery, continues to facilitate appropriation through naming. As Milkman listens to Circe's story, he 
becomes more aware of the machinations of racism which he could not recognize earlier because of his class privileges. Even though his search for gold turns out to be disappointing, Milkman learns to value himself through things other than material possessions: he gamers self-value through being the first member of his family to discover his grandfather's real name. Redeeming his grandfather's name initiates a first step towards the reclamation of his family history and its deep roots in folk traditions.

With every step he makes towards finding the gold, Milkman ends up losing valuable personal belongings like shirts or shoes, items which signify his former acceptance of the values of the dominant culture. For example, Milkman tears his suit, ruins a nice pair of shoes, and breaks his watch while climbing up the steep rocks towards the cave where the gold presumably is. Significantly, Milkman ponders over his father, Pilate, and the hunters who took the same path, but "None of them tore their clothes as he did, climbing twenty feet of steep rock" (251). Inside the cave, Milkman finds out that the gold is not there and there was "nothing at all" (252). Still the journey has greatly improved the condition of his mind: "his mind had begun to function clearly" (257). Gradually, Milkman will realize that obsession over material riches forms the biggest obstacle towards the pursuit of freedom.

When he arrives in Virginia, Milkman's ancestral home, he becomes less appreciative of his father's unnecessary regard of material gains as the basis for personal esteem. In Shalimar, the town named after his great grandfather Solomon, Milkman stops at Solomon's General store to get his car repaired. He instigates the hostility of a group of male bystanders when he thoughtlessly announces his willingness to buy a new 
car if the one he already has is not ready on time. In saying this, Milkman has indirectly posed himself as different from ("and probably superior to?") the townspeople who "looked at his skin and saw it was as black as theirs, but they knew he had the heart of the white men who came to pick them up in the trucks when they needed anonymous, faceless laborers" (266). To the group of men, Milkman is the epitome of the colonizer who refers to the locals as "them," and who enhances his superiority even further when he discloses his desire for a woman. Infuriated by Milkman's manners and his inconsiderate remarks, the men wage a literal battle against him.

A group of older men who watch Milkman defend himself against the young attackers invite him to join a hunting trip. Despite the fact that he does not know how to handle a firearm, Milkman accepts the challenge because "he had stopped evading things, sliding through, over, and around difficulties" (271). The hunt offers Milkman moments of introspection, and gradually he begins to realize that vestiges of his social status and privilege can be obstacles to his survival and his coming together with his own people. Milkman begins to recognize alternatives to his acquired social image, and the hunt teaches him the mechanisms to adapt to real life crises. The text informs us that Under the moon, on the ground, alone, with not even the sound of baying dogs to remind him that he was with other people, his self, the cocoon that was 'personality'-gave way... . So the thoughts came, unobstructed by other people, by things, even by the sight of himself. There was nothing here to help him- not his money, his car, his father's reputation, his suit, or his shoes. In fact they hampered him. Except for his broken watch, and his wallet with about two hundred dollars, all he had started out with on this journey was gone: his suitcase with the Scotch, the shirts, and the space for bags of gold; his snap brim hat, his tie, his shirt, his three piece suit, his socks, and his shoes. His watch and his two 
hundred dollars would be of no help out here, where all a man had was what he was born with, or had learned to use. And endurance. Eyes, ears, nose, taste, touch- and some other sense that he knew he did not have: an ability to separate out, of all the things there were to sense, the one that life itself might depend on (277).

At this point Milkman will be able to understand the meaning of Guitar's earlier comment that a peacock can not fly because of "Too much tail. All that jewelry weighs it down. Like vanity. Can't nobody fly with all that shit. Wanna fly, you got to give up the shit that weighs you down" (179). In the woods, Milkman is free from the cultural bondage the commodity acquisition represents, and eventually he develops the capacity to use his senses. Thus he learns to listen to what "the earth had to say" (279). He even detects the figure of his friend Guitar hiding in the woods ready to kill him because he believes that Milkman has found and kept the gold all to himself. Milkman defends himself against his friend's attack, and towards the end of the hunting trip his own consciousness is transformed: he sheds his old despondent self and hence becomes "exhilarated by simply walking the earth. Walking it like he belonged on it; like his legs were stalks, tree trunks, a part of his body that extended down into the rock and soil, and were comfortable there- on the earth and on the place where he walked. And he did not limp" (281). The disappearance of the limp signals his transformation to a new state of maturity.

A further manifestation of Milkman's change of personality is his admission of his being insensitive towards family members. While in Shalimar, Milkman listens to a blues song the children sing and it reminds him of an old blues song Pilate also sings: 
"O Sugarman don't leave me here," except that the children use Solomon instead of Sugarman. The song reminds him of Pilate and of his old ingratitude towards her and towards his parents whose lives he discarded as unimportant. Recognizing the integrity of the people he has taken for granted, Milkman begins to feel homesick "for the very people he had been hell-bent to leave. His mother's quiet, crooked, apologetic smile. .. The best years of her life, from age twenty to forty, had been celibate, and aside from the consummation that began his life, the rest of her life had been the same ... his father. An old man now, who acquired things and used people to acquire more things. As the son of Macon Dead the first, he paid homage to his father's life and death by loving what that father had loved: property. . . . He loves these things to excess because he loved his father to excess. ... That he distorted life, bent it, for the sake of gain, was a measure of his loss at his father's death. . . His mind turned to Hagar and how he treated her. . . He had used her" $"(300)$.

These moments of introspection take place while the children are still singing the old blues. The song imparts a ritualistic character in its repetition of a "rhythmic, rhyming action game" (303). While watching the children perform the ritual of the song, Milkman begins to interpret the song's references as names of people he has heard about and places he has actually visited. To him, the song is no longer a rhyming verse he has earlier related to a "kind of ring-around-the-rosy or Little Sally Walker game" (264), the song has a tale- most probably a folk tale the background of which he is determined to learn. Not having a pen and nothing to write on except his airplane ticket, Milkman is obliged to listen and memorize the song: 
Come booba yalle, come booba tambee

Whirled about and touched the sun

Come konka yalle, come konka tambee

Left that baby in a white man's house

Come booba yalle, come booba tambee

Heddy took him to a red man's house

Come konka yalle, come konka tambee

Black lady fell down on the ground

Come booba yalle, come booba tambee

Threw her body all around

Come konka yalle, come konka tambee

Solomon and Ryna Belali Shalut

Yaruba Medina Muhammet too

Nestore Kalina Saraka cake

Twenty one children, the last one Jake!

O Solomon don't leave me here

Cotton balls to choke me

O Solomon don't leave me here

Buckra's arms to yoke me

Solomon don't fly, Solomon done gone

Solomon cut across the sky, Solomon gone home

The song tells the story of Solomon, an African slave, who could not tolerate the oppression of slavery and decides to fly back to Africa. He leaves behind his wife Ryna and twenty other children. The only son that he tries to take with him is his youngest 
one Jake whom he drops him soon after he leaps in the air. Milkman is exhilarated with the knowledge that "these children were singing a story about his own people!" (304). The son Solomon fails to take with him is Jake, Milkman's grandfather who also becomes known as "one of those flying African children" (321). The song also refers to Ryna, Solomon's wife, who drops dead on the ground soon after Solomon flies in the air. For Milkman, the song becomes a way of knowing who he is. The fact that he has not been educated in his own culture explains why he did not know himself. Watching the children of Shalimar perform the oral tradition of their people, Milkman learns that identity assertion can be acquired in communal affiliation. Thus he merges himself with the people of Shalimar in accepting, embracing, looking up to the mythical flight of an ancestor. Moreover, the inscription of the folk speech in the song enhances a selfauthenticating language for the community of Shalimar and for Milkman who now considers himself as one of them.

In "Myth as a Usable Past," Marilyn Sanders Mobley contends that the "significance of the song is threefold: for Milkman, it signifies the story of his family; for the community Shalimar, it functions as a kind of cultural glue through the children who learn, sing, and perform it; and for the reader, it serves as an illustration of Morrison's folk aesthetic and mythic impulse at work"(Folk, 127). The folk aesthetic which lies at the heart of Song of Solomon covertly posits an alternative to the characters' psychological enslavement to a white and domineering ideology. For example, towards the end of his visit to Shalimar, Milkman totally ignores the original aim of his visit, which is, the search for relatives with whom Pilate might have entrusted the gold when 
she visited Virginia. Instead of packages full of gold, Milkman goes home with the invaluable discovery of his family history and the indispensable role it occupies in the folk aesthetic of his people.

That Milkman has attained a level of maturity is clear in his acknowledgment of his responsibility in Hagar's hysteria and her subsequent death. The narrative remarks Milkman's significant transformation and his inner growth: "When he went home that night, he walked into the house on Not Doctor Street, Milkman has almost none of the things he'd taken with him. But he returned with a box full of Hagar's hair" (334). At this point it becomes obvious that Milkman has cast out all attributes of the "reformed image" he has previously acquired. As a tribute to his regret for not having loved Hagar, Milkman obtains her hair which becomes the token of his share in the responsibility society has in victimizing women.

Thus the narratives of the two novels warn against the risks of attempting to absorb the norms of an alien ideology. Instead of mimicking the models of a society that poses itself as higher, the narratives advocate identity assertion by embracing the major cultural values the dominant society has dismissed. These texts expose the twentiethcentury psychological enslavement to a dominant culture and its hegemonic valorization of "refined manners," and challenge the very notion of refined manners as a white bourgeois construct. Both Hagar and Pecola are victims of the debilitating strife to adopt the styles of the "reformed image." Claudia MacTeer and Pilate Dead continue to thrive because of their awareness of the subversive subtext the demand for reformed manners entails. Likewise, Milkman sets himself free from his bondage to an alien ideology when 
he gets to know the traditions of his people and the values of his own folk culture. The two novels suggest a return to one's cultural values as alternative sources of valuation and identity assertion.

The next chapter includes a discussion of Morrison's Beloved and the manner in which the narrative raises the consciousness of colonial people against the mainstream of the dominant ideologies which give the oppressed no chance to define themselves on their own terms. In Beloved, the narrative sets the terms of definitions, especially when emancipated subjects of slavery tell their own version of history. To fully understand the integrity of their own experience in slavery, the ex-slaves must reclaim the past in all its fullness. The process of past recovery will disrupt some discourses of history written exclusively from the point of view of the "knowing Subject": the White male master of knowledge. In Beloved it is the slaveholder (Schoolteacher) who posits himself as the subject of knowledge. In re-enacting the past, the ex-slaves Sethe and Paul D will subvert the discourses Schoolteacher has written about "them," and hence tear apart the masks of knowledge he affected through the mastery of language. 


\section{Notes}

'Juliet Mitchell refers to femininity as an imposed masquerade which is often internalized by the female impersonator; in Morrison's two novels white beauty can be looked upon as a form of femininity black women are required to submit to; whiteness therefore is another form of the feminine masquerade that also has debilitating effects on black girls. 
Resisting the Colonizer's Rhetoric: Morrison's

Beloved 
It is not by confining one's neighbor that one is convinced of one's sanity. Dostoyevsky, Diary of a Writer

The minority's attempt to negate the prior hegemonic negation of itself is one of its most findamental forms of affirmation. Abdul R. JanMohammed and David Lloyd, Towards ory of Minority Discourse

The purpose of this chapter is to pinpoint the importance of Toni Morrison's Beloved in ripping the masks of colonialism and exposing the ploy of control intrinsic in the colonial monopoly of social sciences. To rip the veil of the colonial immaculate image, Morrison has to disclaim the norms of decorum embraced by her literary forebears, the authors of the nineteenth-century slave narrative. In trying to meet the modes of chastity their white, female contemporaries strongly acknowledged, the authors of the slave narrative omitted important incidents of sexual oppression the slaveholders had directed at them. In Beloved, Morrison manages to fill in the gaps of the silences of her literary forebears by candidly recounting the incidents of rape slave women were subjected to. The narrative of Beloved is unprecedented in exposing the sexual assaults directed at African girls who were forced on board slave ships. In this sense, Beloved becomes a representative of a race of women who "lost their ribbon" due to the rape directed at them by the men "without skin" (181). Similar to the manner in which Song of Solomon and The Bluest Eye disown the traditions of imitating and absorbing white values, the narrative of Beloved withdraws from the traditions of writing which accepted the masks of the dominant culture. Unlike the nineteenth-century slave narrators who wanted to please their white readers, Morrison breaks from the traditions of silence and tells the whole truth about the brutality of colonialism. 
In exposing slavery's machinations, Toni Morrison's Beloved pays particular attention to ethnographic and historicist scholarship as a tool the system of slavery used in legitimizing slave ownership. In Beloved, the narrative consists of a multiplicity of discourses that disrupt the ethnographer's derogatory study of the slaves. Sethe, Baby Suggs and paul D question steadily Schoolteacher's definitions of themselves, challenging theories of inferiority the ethnographer-- Schoolteacher- assigns to "them." In exchanging their own histories and personal biographies in an oral form, Sethe and Paul D introduce a counter-discourse that dismantles Schoolteacher's description and his (master)narrative of history. Baby Suggs' ritual in the Clearing is another counterdiscourse that deplores the colonial appropriation of slaves and its literal inscription of black bodies. The ritual subverts oppressive discourses by inviting the former oppressed to rehabilitate the self against colonial negation. Beloved, the child that Sethe has killed in refusing to give back to the slaveholder, also insists on telling her own version of history. She exposes the cruelty of the slave holding system and the manner in which it has kidnapped generations of grandmothers from home and forced them on board slave ships. In Beloved, it is the ex-slaves who insist on telling their own experience in slavery, disrupting discourses of history written only from the point of view of the critic as white and male.

Based on panopticon observation and "essential" descriptions of the slaves on his farm, Schoolteacher has written a book attempting to ascertain the inferiority of the black race. Schoolteacher's attempts to construct the Otherness of black people falls directly into the colonial project which sought to legitimize itself by manipulating social and 
political sciences. In post-colonial studies, critics such as Homi Bhabha, Edward Said and Eijaz Ahmad have exposed the mechanisms colonial systems used and are still using in justifying appropriation and control of other peoples, their manpower and sometimes home lands. Homi Bhabha, for example, comments on how the "objective of colonial discourse is to construe the colonized as a population of degenerate types on the basis of racial origins, in order to justify conquest and to establish systems of administration and instruction" ("The Other" 75). In Beloved, Schoolteacher's classification of the slaves as "degenerate" types has forced the slaves to escape from Sweet Home Farm and take all the risks implicated in the deed. Some of the slaves, namely, Sixo, Halle and Paul F, perished in the process. Still their escape is a strong commentary on their refusal to accept Schoolteacher's enslaving project.

On Sweet Home Farm, the slaves intensely resent Schoolteacher's descriptions of their bodies and habits, and the constancy of his scrutinizing gaze. Schoolteacher's descriptive devices form an example of Aijaz Ahmad's criticism of the category of the "essentially descriptive." According to Ahmad, description can never be "ideologically or cognitively neutral." Ahmad argues, "It was by assembling a monstrous machinery of description- of our bodies, our speech acts, our habits our, conflicts and desires, our politics, our socialities and sexualities, in fields as various as ethnology, fiction, photography, linguistics and political science- that those discourses were able to classify and ideologically master colonial subjects, enabling the transformation of descriptively verifiable multiplicity and difference into the ideologically felt hierarchy of value" (n Theory 99). In Beloved, Morrison's narrative attests to the dangers of attributing 
categories to subjects through description. Nevertheless, Beloved subverts the hierarchy of significance "description" confers by virtue of concentrating more on the awareness of the slaves of their status as subjects of "description" and their negation of that status. As Foucault might have it, the slaves have obtained "autonomous agency by producing and then recuperating their own opposition."1 Edward Said is among the postcolonial theorists who rigorously critique the ongoing practices of colonialism and the benefits it gathers by utilizing forms of anthropology and historicism for purposes of domination and hegemony. In his essay "Representing the Colonized: Anthropology's Interlocutor," Said is keen on exposing the conducive role anthropolgy has in inventing and furthering the Otherness of subject peoples. As Said sees it, anthropology includes elements of "fetishization and relentless celebration of 'difference' and 'otherness' [which] can therefore be seen as an ominous trend" ("Anthropology" 213). Beloved resonates the cultural concerns of postcolonial theory, especially when it offers a narrative that counteracts the rhetoric of Otherness implicit in Schoolteacher's discourses.

At Sweet Home farm, Schoolteacher asserts his authority over the slaves by virtue of postulating himself as subject of knowledge. He instructs his students to define Sethe by "putting her human characteristics on the left; her animal ones on the right. And don't forget to line them up" (193). Schoolteacher employs the whip to suppress every attempt on the part of the slaves to affirm their humanity against his demeaning authority and his fraudulent claims to knowledge. The narrative tells us that Sixo, one of the slaves on the farm, gets whipped even more when he resists Schoolteacher's beating in order to make him understand that "definitions belong to the definers- not the defined" (190). In her 
essay "Talking back to Schoolteacher: Morrison's Confrontation with Hawthorne in Beloved "Caroline Woidat contends that "schoolteacher stands as the quintessential figure of white male authority, wielding the power of the word as well as the whip" ("Talking" 528). Lurking in Schoolteacher's plan to observe, define and interpret the slaves is the desire to establish the cultural stereotype that legitimizes slavery. To do so, he needs to acquire knowledge of the slaves and he wants to use this knowledge in controlling their lives. He obviously carries out his research in accordance with a "formula" which facilitates appropriation and domination. ${ }^{2}$ However, Schoolteacher's invented formula will not sustain the desired control over the slaves. The slaves subvert Schoolteacher's study by simply dismissing it as a joke. Sethe's following comment makes it clear that the slaves have depicted Schoolteacher's ignorance and they are laughing at it:

Schoolteacher was telling us things we couldn't learn. I didn't care nothing about the measuring string. We all laughed about that- except Sixo. He didn't laugh at nothing. But I didn't care. Schoolteacher wrap that string all over my head, 'cross my nose, around my behind. Number my teeth. I thought he was a fool. And the questions he asked was the biggest foolishness of all (191).

What the slaves could not learn is the inferior status Schoolteacher is trying to allocate to them. And, apart from Sixo, they all consider his interpreting study of themselves as the "biggest foolishness." However, Sethe begins to realize the danger of Schoolteacher's theoretical observation when she learns that he is writing a book about "us," meaning herself and other slaves on the farm. What is even worse is the fact that he has been using the ink she herself makes in writing his notes, making her thus an 
accomplice of his writing. Sethe greatly resents her involvement in Schoolteacher's writing, as she later tells Paul D, "I made the ink, Paul D. He couldn't have done it if I hadn't made the ink" (271). Like Sixo, she finally gets to learn the danger of shoolteacher's form of scholarship and therefore she desists from sharing the other's trivializing humor of the matter. She states,

He liked the ink that I made. It was [Mrs. Garner's] recipe, but he preferred how I mixed it and it was important to him because at night he sat down to write in his book. It was a book about us and we didn't know that right away. We just thought that it was his manner to ask us questions. He commenced to carry round a notebook and write down what we said. I still think it was them questions that tore Sixo up. Tore him up for all time (37).

The major insult directed at Sethe while at Sweet Home is the draining of her maternal milk by Schoolteacher's nephews. When Sethe reports the incident to her mistress, Schoolteacher whips her even more. His lash leaves Sethe's back irrevocably marked with what looks like a chokecherry tree. In Foucault's words, Sethe's body “is employed as a standard of discipline and as a basis for regulations" (The History 146). Schoolteacher's whipping is indicative of the disciplinary mechanisms the system of slavery used to impose silence and to maintain and regulate hierarchies of power. In Foucault's contention, the scar on Sethe's back guarantees "relations of domination and effects of hegemony" (The History 141). Sethe, however, resists Schoolteacher's controlling disposition by escaping Sweet Home. She also manages to get her three children out of there, proving thus the futility of his discipline to make her accept the abasing fate he is trying to impose on her. Together with the baby she gave birth to 
during her escape, Sethe arrives at 124 Blue Stone Road, the free household of her mother-in-law Baby Suggs. Her escape asserts her humanity and demonstrates that Sethe is the only possessor of herself. It also dismantles schoolteacher's invented entitlement to slave ownership. Instead of being an object of investigation, Sethe has asserted her subject position.

When Schoolteacher finds Sethe and wants to claim her and hers as property, Sethe prefers to kill her baby daughter rather than give her back to slavery. She murders Beloved in order that "No one, nobody on this earth, would list her daughter's characteristics on the animal side of the paper" (251). Since her children are the best thing she ever is and has, Sethe is determined that "Whites might dirty her all right, but not her best thing, her beautiful magical best thing- the part of her that was clean"(251). By killing her daughter, Sethe has not only denied Schoolteacher the right to "own" her and her family but she has also taken away from him the object of ethnography. Implicit in the act of violence is also Sethe's response or "interlocution" with the colonizer who has enforced silence upon her through whipping. In Edward Said's words, Sethe epitomizes the interlocutor who "simply refuses to talk, deciding that only a radically antagonistic, perhaps violent riposte is the only interlocution that is possible with colonial power" ("Anthropology's" 210). Sethe's act of murdering her own child in order to "out-hurt the hurter" (234) is a commentary on the violent choices the system of slavery imposes on its victims.

Schoolteacher's attempt to control the slaves through the mastery of language is reminiscent of the 19th century stance prevalent among some intellectuals who 
attempted to enact the Otherness of colonial people in discourses of knowledge. In his pioneering study Orientalism, Edward Said critiques the participation of some Westem intellectuals in the process of relegating the Orient to a status inferior to that of the Occident. Specifically, Said deplores some ethnographic researchers and their claim to objective observation. ${ }^{3}$ According to Said, colonial ethnography failed to recognize its complicity in its cultural standpoint. Colonial ethnographers have often projected their own cultural attitudes and values onto their own study of "inferior" cultures. In Orientalism, Said contends that "no production of knowledge in the human sciences can ever ignore or disclaim its author's involvement as a human subject in his own circumstances" (11). The observer therefore is necessarily involved in acts of scrutinizing and disciplining especially when he sets himself or his own culture (the pronoun is used advisedly) against other cultures as a kind of surrogate. In Beloved, Morrison critiques the systematic discipline embodied in the ethnographic analysis of other peoples. Schoolteacher's "descriptive" study of the slaves' bodies, their habits and their styles of living is akin to the desire to discipline and control, or rather the desire to control through discipline. At Sweet Home Sethe is aware of the disciplining gaze of Schoolteacher and the purposes of his theoretical observation. She tells Paul D, "I am full God damn it of two boys with mossy teeth, one sucking at my breast the other holding me down, their book-reading teacher watching and writing it down" (70). What she both depicts and resents in Schoolteacher's gaze is the eye of the scrutinizer and his patronizing style which is even more demeaning than his whip. 
Moreover, Schoolteacher's study is likely to consolidate the construction of an Africanist persona which, in Morrison's words, illuminates how "a non-white Africanlike (or Africanist) presence was constructed in the United States and the imaginative uses the fabricated presence served" (Playing 6). According to Morrison, the process of "organizing American coherence through a distancing Africanism became the operative mode of a new cultural hegemony" (Playing 12). In Beloved, the process of lif-promotion by diminishing the "other" becomes clear in Schoolteacher's invention of cultural stereotypes which, according to Said, re-enforce the "dreadful secondariness of people" ("Anthropology" 207). In a sense, Schoolteacher becomes a good example of what Edward Said censures in speaking of the learned voice that "speaks and analyzes, amasses evidence, theorizes, speculates about everything- except itself"' (212).

In her essay "Unspeakable Things Unspoken: the Afro-American Presence in American Literature" Toni Morrison comments on the one-sided relation of the white colonizer towards the slaves. Morrison states, "One could write about them, but there was never the danger of their 'writing back.' Just as one could speak to them without fear of their "talking back." One could even observe them, hold them in prolonged gaze, without encountering the risk of being observed, viewed or judged in return" (Criticism 25). Morrison's remark can also be taken as critique of "white" historicism and its instrumental role in subjugating and marginalizing colonial people. As counter-history, the narrative in Beloved disrupts the "apparent linearity" of Schoolteacher's historicism. For example, Sethe generates her history within the realms of "rememory," testifying a wrunter-memory" to colonialism, to the brutality and dehumanization to which the 
slaves of Sweet Home were subjected. When the characters rememory their experience in slavery, they also rewrite history from the point of view of the oppressed. As Betty Jane Powells argues, "The gift of 'rememory' allows characters to remember and reinvent not only their own stories, but stories of others as well. It offers the means of sharing and diffusing the pain, lifting the burden of memory when it becomes unbearable" ("Will" 108). Only through collective sharing of past stories and experiences, will the characters be able to "talk back" to the colonizer and challenge colonial history by producing discourses that counteract hegemonic colonial histories.

Being perpetually thwarted by a past that "threatens to take over the present" (99), Sethe is determined to repress all remembrances of that past and keep it "at bay." The same enormous past has also driven Paul D to a state of unbreakable silence. He thereby chooses to lock his past in a tobacco tin lodged in his chest, and, "By the time he got to 124 nothing in this world could pry it open" (113). For both Sethe and Paul D the silence loosens its grip over the past when they start to share their rememories. The text notes "Her story was bearable because it was his as well-to tell, to refine and tell again" (99). Because of Paul D, Sethe finally gets to understand her husband Halle and abolish the anger she has fostered against him for not showing up at the right time and place for their planned escape. From Paul D's "rememories," Sethe learns that Halle was driven insane by watching Schoolteacher and his nephews beat her back and drain her milk.

Likewise, Sethe helps Paul D to disclose the memory of Sixo's execution by fire and the way Sixo confronted death with a fit of laughter and a song, provoking Schoolteacher to shoot him to silence. Laughter in this case is a discourse that 
counteracts Schoolteacher's malevolence. Sixo's laughter is an assertion of his refusal to be defeated by Schoolteacher despite the latter's capacity to destroy him. As Helene Cixous might have it, Sixo's laughter is the only weapon of "causing trouble and resisting death" ("The Laugh" 315 ). Paul D also recalls the silencing effect of the bit of iron Schoolteacher inserted in his mouth and how "offended the tongue [as] held down by iron, how the need to spit is so deep you cry out for it" (71). The iron bit exemplifies the manner in which slavery imposed silence on its victims. However, the sharing of stories and personal histories allows the former slaves to produce a discourse that counteracts the slaveholder's hegemonic imposition of silence.

More painful than the iron bit was Paul D's recognition of his inferior status to roosters and other animals on the farms, he tells Sethe, "Mister [a rooster], he looked so ... free. Better than me... Stronger, tougher. Mister was allowed to be and stay what he was. But I wasn't allowed to be and stay what I was... Schoolteacher changed me. I was something else and that something was less than a chicken sitting in the sun on a tub" (72). In his coming together with Sethe, Paul D has gathered the courage to say the unsayable, to tell his painful story of oppression. Rememories become a path for the characters to exchange their personal autobiographies orally, and, as Kathryn Trees explains, "the historical function of autobiography produces discourses to counter existing histories" ("My Place" 69). In "Resisting Closure" Brenda Marshall argues that "the history told in Morrison's Beloved is also a will to power: a strategy to allow a people to be a subject of its own history, not as marginalized 'others,' not as addenda" ("Resisting" 184). Drawing on Marshall's comment, we can conclude that the history 
initiated in the realms of Rememories is a history of displacement-- disrupting Dhoolteacher's historicism.

The process of history reclamation will be incomplete unless the characters disclose occurrences in their past they particularly find "unspeakable." The gravest difficulty that often confronts the former colonized is to come to terms with the enormity of their past. The narrative of Beloved registers the amnesia the former slaves have developed regarding their past in slavery. When Sethe inadvertently recollects the image of her mother's hanged body, she feels impelled to do "something with her hands because she was remembering something she had forgotten she knew. Something privately shameful that had seeped into a slit in her mind right behind the slap on her face and the circled cross" (61). So far Sethe has tried to suppress the memory of colonial and racial oppression in slavery. She also wants to protect her children from the colonial past that constantly thwarts her present. She warns Denver:

Where I was before I came here, that place is real. It's never going away. Even if the whole farm- every tree and grass blade of it dies. The picture is still there, and what's more, if you go there- you who never was there- if you go there and stand in the place where it was, it will happen again; it will be there for you, waiting for you. So, Denver, you can't never go there. Never. Because even though it's all over- over and done with-it's going to always be there waiting for you. That's how come I had to get all my children out. No matter what (36).

The place Sethe is talking about is her previous home in Kentucky, the place that she and other slaves named Sweet Home because Mr. Garner, the slaveholder, allowed the slaves to learn to read and write. Sweet Home was also sweet because Garner announced and 
named his male slaves men when all the slaves of Kentucky were labeled children (125). Upon Garner's death, his wife invited her brother-in-law Schoolteacher and two of his nephews to stay with her because "people said she shouldn't be alone with nothing but Negroes" (197). When Schoolteacher proclaimed himself as the new master, the slaves at Sweet Home realized that Gamer's liberal style of slave holding did not offer them the freedom to question Schoolteacher's authority. At this point, the slaves find out they were only "Sweet Home Men at Sweet Home. One step off that ground and they were trespassers among the human race" (125). With Garner's death, the slaves become deprived of their entitlement to manhood, especially when Schoolteacher attempts to break "into children what Gamer had raised into men" (220).

Sethe's husband Halle knew that slavery is a plague even when slaveholders are as generous as Garner presumably is. Not wanting his mother Baby Suggs to spend her remaining years in bondage, Halle buys her out of slavery by renting his work. Only as a free woman will Baby Suggs recognize the inequities of slavery and the fact that Garner's slaveholding style was no more than a "special kind of slavery" (140). At this point only, Baby Suggs will understand the reason of Halle's determination to buy freedom for her. The narrative comments thus,

What does a sixty-year-old slave woman who walks like a three-legged dog need freedom for? And when she stepped foot on free ground she couldn't believe that Halle knew what she didn't; that Halle, who had never drawn one free breath, knew that there was nothing like it in this world. It scared her (140). 
When Garner introduces Baby Suggs to the Bodwins, he wants her to assert his generosity as a slaveholder. He therefore interrogates her: "Did I let Halle buy you or not?" (146). Baby Suggs says yes to his answers when she silently meditates on how "you got my boy and I'm all broke down. You be renting him out to pay for me way before I'm gone to Glory" (146). This makes it clear that there is no such thing as liberal or democratic styles of slaveholding. Hence memories of Sweet Home necessarily invoke racial memories that redefine the farm as "not sweet and it sure wasn't home (14).

Caught up between the desire to recall the past and the need to repress it, Sethe is still unable to brief Paul D on the "perfect death of her crawling-already? Baby" (99). ${ }^{4}$ Under the pretext that "time will come" (99), Sethe has postponed all mentioning of the baby daughter she was forced to kill. By avoiding history, Sethe is acting upon the impulse of denying neither the responsibility nor the guilt of the murder of Beloved. Homi Bhabha reminds us that Morrison's Sethe is an epitome of the "painful ethical position of a slavewoman who is pushed to infanticide" (The Location). The mere presence of the ghost of Beloved within the premises of 124 Blue Stone Road is evidence of the guilt Sethe experiences as a result of having misdirected her anger. Consequently, she allows the ghost of Beloved to haunt 124, her house on Blue stone Road. Thus, the narrator's statement that “124 WAS SPITEFUL. Full of baby's venom" (3) is a commentary on Beloved's being the "haint" of the murdered child and on Beloved's becoming metaphor of the racial memory Sethe is trying to repress. Nevertheless, Sethe allows Beloved to run her own household and to control her life. For example, the ghost of Beloved caused her two brothers Howard and Buglar to part with Sethe after the ghost 
frightened them when "two tiny hand prints appeared in cake" (3). This incident testifies to Beloved's indomitable authority over the affairs of her mother's household. Beloved also will not allow Sethe to enjoy the novelty of a man's appearance in her life. As Rebecca Fergusson observes: "when Paul D touches the scars left on Sethe's back from her beating, the house explodes with the baby ghost's disturbance, and we witness the force of Beloved's jealousy, her will to obstruct any living person from appropriating Sethe's past, her guilt or her responsibility" (Feminist Criticism 113). When Paul D fights the ghost and dismisses it out of the house, Beloved takes the corporeal form of a teenage girl that arrives at 124 to stay.

Beloved's physical appearance and her thirst for storytelling make it less difficult for Sethe to "rememory" the past. To Beloved's inquiry that "your woman never fixes your hair?" (60), Sethe's spontaneous response is that she never knew her mother. In remembering her mother, it is inevitable for Sethe to rememory the sign of a cross left on her mother's breast by the slaveholder. Beloved forces on Sethe the memory of the one and the last time she met her mother, the time when she requested that she too be inscribed with a mark similar to that of the mother's. As an answer to her request, Sethe receives a slap on the face. The mother's response is indicative of her unquestionable refusal to become an agent of slavery by marking her daughter's body with the "brand of ownership." Sethe's remembrance forms an example of the rememory Mark Ledbetter defines as "the rememory of things that never die- experiences of a people- the violence perpetuated on the body because of its race and its gender" ("An Apocalypse" 162). 
The imaginary resurrection of Beloved encourages Denver, Sethe's other daughter, to (re)construct her mother's history through storytelling. In order for Denver to be able to indulge Beloved's curiosity about the past, she has to imagine it, to revive the forgotten histories of her parents. When she tells Beloved the story of Sethe's escape from slavery, Denver also revisits the places where her mother had been and she listens again to Sethe's conversations with Baby Suggs. To be able to understand their mother, both Denver and Beloved assiduously work to refigure and reconstruct Sethe's past. The narrative emphasizes the sisters' involvement in the act of storytelling: "Denver spoke, Beloved listened, and the two did the best they could to create what really happened, how it really was" (111). Denver tells Beloved that she herself was born during Sethe's escape across the Ohio River, that a white girl named Amy Denver had helped Denver's birth.

To acquaint Beloved with what Sethe has gone through prior to her escape, Denver repeats the conversations that took place between the two female fugitives who transcended their race difference and bonded together against oppression. Denver explains the effects that Sethe's scars had on the fugitive Amy Denver. Once she sees Sethe's back, Amy Denver exclaims, "It is a tree, Lu. A chokecherry tree. See, here is a trunk- it is red and split wide open, full of sap, and this here is the parting of the branches ... What God had in mind, I wonder. I had me some whippings, but I don't remember nothing like this" (79). What Amy Denver sees in Sethe's back is the mark of slavery, the mark that she herself lacks because has been a maid in the household of a cruel master but never a slave. Hence her consequent comment, "Whoever planted that tree 
beat Mr. Buddy by a mile. Glad I ain't you" (79). In not wanting to be in Sethe's position, Amy Denver separates herself from the oppression Sethe has been exposed to. With Sethe, however, Amy Denver has established the strongest of maternal ties, helping the birthing of Denver, trying to wipe out Sethe's pain by massaging her swollen feet and finally giving her a life-time word of advice: "Can't nothing heal without pain" and "Anything coming back to life hurts"(78). When she reports her mother's escape, Denver along with Beloved, tries to understand the enormity of Sethe's past and the tribulations which pushed her to infanticide. As she incorporates memories of her mother into a narrative of her own, Denver is able to re-enact the past. She thereby comes to understand the memory of maternal violence, the fear lest the thing "that made it all right for my mother to kill my sister could happen again" (205). This epitomizes Denver's fear of Schoolteacher and the unpredictable danger he posits as the outsider who "comes from outside this house, outside this yard, and can come right on in the yard if it wants to" (205). Denver's precaution stems from the inherent fear lest Schoolteacher should happen to stop again at 124, and his appearance "might make [Sethe] do it again" (205). For this reason, she has never ventured outside the premises of 124 , wanting to keep a watch over the yard so "it can't happen again and my mother won't have to kill me too" (205).

Denver ventures out of the premises of 124 only after she witnesses Sethe's entrapment by the ghost of Beloved, her entanglement with a past that threatens to "take possession of the present" (256). She then decides to put an end to her solitary confinement and seeks the community's help to save her mother. Barbara Blair contends 
that, in falling back to the community, Denver "recovers not only her words and opinions, but also her place in the community" ("Textual" 52). Indeed, by allying with the community, Denver finally attains a clear sense of her cultural identity. Beloved emphasizes the pertinence of communal alliance for purposes of healing and identity recovery. That the community share their experience of the past they find "unspeakable" becomes obvious in their disfigured bodies. Betty Jane Powell observes that the community share the inability to "recognize their own bodies, just as they are unable to tell their whole stories" ("Will" 106). Salvation therefore is attained through the "gathering together of the neighbors' bodies and stories in freedom" ("Will" 107). Morrison's narrative gives emphasis to the importance of healing as a process achieved in the collective. The ritual that Baby Suggs leads in the Clearing becomes a prominent example of how injured people can obtain recovery by coming together. Baby Suggs takes the role of spiritual healer and nurturer when she realizes that her heart is the only part in her that slavery has not impaired. The narrative comments, "slave life had 'busted her legs, back, head, eyes, hands, kidneys, womb and tongue,' she had nothing left to make a living with but her heart- "which she put to work at once" (87). In the Clearing, she preaches that her people must learn to love themselves, love their bodies, especially the parts of their bodies that colonialism has severely oppressed.

Unlike preachers, Baby Suggs never tells her people to "clean up their lives or go sin no more" (88). Rather, she tells them that "the only grace they could have was the grace they could imagine. That if they could not see it they would not have it (88). In her sermon, Baby Suggs insists that the former oppressed embrace their physical 
eagmentation and love those particular parts which carry the mark of physical abuse. In a sense, the scars become a way for slavery to face its new destabilized image. Especially when embraced by black subjects, the scars are likely to subvert slavery's legitimizing discourses. Furthermore, the marks on black bodies become authorization for membership in the community. Hence Baby Suggs addresses the community on the basis of bodily disfigurement they share in common: "in this here place, we flesh; flesh that weeps, laughs; flesh that dances on bare feet on the grass ... Love it hard. Yonder they do not love your flesh ... Love your hands! they ain't in love with your mouth ... they will see it broken and break it again ... this is flesh I am talking about here, flesh that needs to be loved ... Feet that need to rest and to dance; backs that need support, shoulders that need arms, strong arms I am telling you and all your inside parts, the dark, dark liver- love it more than your life-holding womb, and your life-giving private parts, hear me now, love your heart. For this is the prize" (88-9). In order for identities to heal, members of the black community must acknowledge their "otherness," embrace the wounds that define them as different from the perpetrators of violence. The scars of slavery are thereby marks of identity that oppression cannot deprive them of as it has done with their children and other forms of personal liberty and property.

By virtue of their wounds, the black subjects voice their defiance against oppressive authorities. For retrieval or creation of independent identities, the sermon in the Clearing invites the oppressed to bind together and acknowledge the wounds they all have in common. In Powell's words, Baby Suggs "pleads for self-assertion with communal overtones"("Will,"105). As JanMohammed and David Lloyd might see it, 
Baby Suggs stands for the oppressed individual who "coerced into a negative, generic -ject-position, responds by transforming that position into a positive collective one" (Towards 10). The "you" and "your" she uses is collective. It refers to every member of the community including herself. Baby Suggs stands as example of Kwame Anthony Appiah's statement: "the African asks always not 'who am I?' but 'who are we' and 'my' is not 'mine' alone but 'ours"' (In My Father's 76).

However, the arrival of Schoolteacher and his group in 124 is likely to disrupt the sermon in the woods. From then on, Baby Suggs abstains from saying "The Word" (178). Baby Suggs has greatly resented the community's failure to warn her of the arrival of schoolteacher. The community, on the other hand, has condemned Baby Suggs for garnering unnecessary pride when she gives a feast in honor of Sethe's arrival. The feast has perpetually isolated Baby Suggs from her community and broken the coalition in the group together with the identity recovery sought in the collective. Consequently, Baby Suggs abandons the sermon in the Clearing and she resigns herself to meditating on colors, deciding therefore that "Her past has been like her present- intolerable- and since she knew death was anything but forgetfulness, she used the little energy left her for pondering over color" (4). Despite the sixty years she spent as a slave and the loss of almost all her children to the people who "chewed her life and spit it out like a bone fish bone" (177), it is in freedom that Baby Suggs' spirits are finally broken. Her feeling of self-worth diminishes after she witnesses Schoolteacher's arrival, the community's abandonment and Sethe's act of slaying her daughter. When Stamp Paid pleads with her not to quit the ritual of the Clearing and reminds her that she alone is gifted with "The 
Word," Baby Suggs responds, "that's one other thing took away from me" (178). Despondently, Baby Suggs begins to view herself as no more than "a nigger woman hauling shoes" (189). According to Betty Jane Powell, Baby Suggs' isolation from the community and her withdrawal into the dream world of color are likely to dissolve "whatever gains toward self she has appropriated" ("Will" 107).

While in embrace with the community, Baby Suggs is able to acquire an identity position and to transcend the many absences in her life. For example, when she arrives at the Bodwins' household as a free woman, she is still overwhelmed by the grave amount of her losses: she ponders over what she once had and lost and what she never lost because she never had. The narrative tells us, "Sad as it was that she didn't know where her children were buried or what they looked like if alive, fact was she knew more about them more than she knew about herself, having never had the map to discover what she was ... Could she sing? (Was it nice to hear when she did?) Was she pretty? Was she a good friend? Could she have been a loving mother? A faithful wife? Have I got a sister and does she favor me? If my mother knew me would she like me?" (138). Here she is certainly meditating over a "non-identity" status and what she should do about it. To reassert her identity, she renames herself Baby Suggs and eliminates the name Jenny the system of slavery assigned to her. She then starts looking for her children. Not being able to locate any of them, she substitutes the community of free slaves for the family she once had. At the time, 124 was said to be a "cheerful, buzzing house where Baby Suggs, holy, loved cautioned, fed, chastised and soothed" (86-7). When abandoned by the 
community, the house, "veiled over and shut away," becomes the "plaything of spirits and the home of the chafed" (86).

Sethe as well has suffered keenly from the community's abandonment. Friends and neighbors have been angered by Sethe's murder of her daughter and they condemned the "unnecessary" pride the murder implicates. Frightened when he leams the extremity of Sethe's response to Schoolteacher's arrival, Paul D also abandons her. He thinks: "This here Sethe didn't know where the world stopped and she began ... more important than what Sethe had done was what she claimed. It scared him" (164). Said in the negative, Paul D's last statement embodies the truth about Sethe. Central to our present concern is Brenda Marshall's insight into the critique of subjectivity in Beloved and the manner in which the narrative strongly contests the notion of the "traditional humanist concept as white, male, propertied, the tautological subject whose existence is verified in his innate power to think himself" ("Resisting" 181). According to Marshall, Paul D's last comment portrays Sethe as "blurring the distinction between self and others, which in Beloved takes the form of Sethe's inability to see herself as separate from her children, a blurring which reinforces the concept of the subject as both constituted and constituting" ("Resisting" 181). Sethe is seen as a subject both constituted and constituting not only in her inseparability from her children but in the inability to separate herself from the community. Prior to Schoolteacher's arrival, Sethe has merged her life with those of her neighbors. During that time, Sethe has known what it feels like to be able to ally with the community, to be part of their debates and to share their stories 
and past sufferings. Unfortunately, the era of freedom has lasted only for twenty eight days, the time she remembers as

Days of healing, ease and real-talk. Days of company: knowing the names of forty, fifty other Negroes, their views; habits; where they had been and what done; of feeling their fun and sorrow along with her own, which made it better. One taught her the alphabet; another a stitch. All taught her how it felt to wake up at dawn and decide how or what to do with the day. That's how she got through the waiting for Halle. Bit by bit, at 124 and in the Clearing, along with the others, she had claimed herself. Freeing yourself was one thing; claiming ownership of that freed self was another (95).

Thus Sethe can claim herself as a free person only by merging the boundaries between her(self) and others. When isolated from the community, Sethe has claims to nothing except the past she finds unspeakable. She tells Paul D, "I got a tree on my back and a haint in my house, and nothing in between but the daughter I am holding in my arms" (15). Sethe here tells the truth of the literal inscription and the psychological ailment inflicted on her by the Southern institution of slavery.

When she decides that she too would shun the community who could not understand the integrity of her reaction to the slaveholder, Sethe has to face the past alone, and that past has confounded her by virtue of its grievousness. Even in freedom, Sethe suffers from the emotional entrapment to past slavery, especially when that past comes back to haunt her as the ghost of the daughter she murdered. In its hauntedness, the past extends to include Sethe's painful experience and the experience of a whole race that suffered under slavery. To Sethe, Beloved is not only the daughter she slaughtered, 
but she is a metaphor for a whole generation of mothers, particularly her own mother who was kidnapped from Africa and brought on board of the slavers. Beloved registers the experience of the Middle Passage in the same broken language that Sethe's mother spoke (62). To Stamp Paid, Beloved represents all the black daughters victimized in slavery, and Sethe's house entombs the incredible suffering of a people in oppression. While eavesdropping behind Sethe's door, Stamp Paid hears a language he cannot understand, still he knows who the speakers are: "This time, although he couldn't cipher but one word, he believed he knew who spoke them. The people of the broken necks, the fire cooked blood and black girls who had lost their ribbons" (181). Even in misery, Sethe cannot see herself as separate from her own people, and, in this way, her personal world blends with the interpersonal, with the sorrows of those who have been in slavery. The distance that Sethe and the community draw between each other will further Sethe's submersion in the past. Paul D's disappearance from 124 has broken Sethe's last tie to the outside world. Beloved now has Sethe all to herself and she is determined to chain her to the past, to the world of storytelling she endlessly craves. The past now has eaten up Sethe, and the narrative tells us that "The bigger Beloved got, the smaller Sethe became. ... Beloved ate up her life, took it, swelled up with it, grew taller on it. And the older woman yielded it up without a murmur" (250). In Powell's words, "Sethe regresses into a kind of masochistic remembering in which frenzied storytelling saps her of agency- she becomes Beloved's possession" ("Will" 111). Although Morrison strongly suggests Audre Lorde's contention of how "in ignoring the past, we are encouraged to repeat its mistakes" ("Age" 283), the narrative of Beloved points out the dangers of too much 
obsession with the past. Sethe shows how living in the past necessarily entails a repetition of its mistakes. Even the community that has shunned Sethe a long time ago for her "prideful" and "misdirected" reaction against the slaveholder's arrival, has now realized the danger of Sethe's living in the past and they are determined to expel its ghost. The community will mutually agree with Ella's assumption that "Whatever Sethe has done, [she] didn't like the idea of past errors taking possession over the present" (256).

When faced with the possibility of Beloved's being taken away, Sethe again resorts to violence. This happens when the community gathers together to exorcise the ghost of Beloved. Among the faces of the people she has known, Sethe locates the figure of Edward Bodwin, and, mistaking him for Schoolteacher, she attempts to attack him with a cutting tool. This time, however, Ella and the other women interfere to prevent Sethe from perpetrating another act of violence. Morrison therefore cautions against the possibility of repeating the mistakes of the past when people have too much connection with it. What remains at stake here is the question of why should Sethe mistake Edward Bodwin, a former Abolitionist, for a slaveholder. According to Sethe, the need to protect her daughter from the atrocities of the slaveholders has induced the murder of Beloved. She tells Beloved, "anybody white could take your whole self for anything that came to mind. Not just work, kill, or maim you, but dirty you. Dirty you so bad you couldn't like yourself anymore. ... And though she and others have lived through and got over it, she can ever let it happen to her own" (251). 
Acting upon the impulse of protecting her daughter, this time she directs her attack against the person she mistakes for the aggressor. Could Morrison be making a comment on the fact that some of the Abolitionists were not much different from slaveholders? In Edward Bodwin's anti-slavery stands there are evidences of his subtle involvement in furthering the inferior status of black people. In reminiscing over the days of active Abolitionism, Edward Bodwin asserts,"Nothing was as stimulating as she old days of letters, petitions, meetings, debates, quarrels, rescue and downright sedition. ... Good years, they were, full of spite and conviction" (261). In his essay "Imperialist Nostalgia," Renato Rosaldo reminds us that agents of a dominant culture recollect fondly the old ways they are in one way or another responsible for destroying. Rosaldo writes, "The agents of colonialism yearn for the very form of life they traditionally altered or destroyed" (Culture 69). Bodwin's nostalgic remembrance of the old days betrays his involvement in the very system he was trying to destroy. For him, Abolition has probably been a mechanism for consolidating the self ("the colonial self?") against slavery and the slaves as a superior Other. The narrative itself reminds us not to trust the Bodwins, brother and sister who "gave Stamp Paid, Ella and John clothes, goods and gear for runaways because they hated slavery worse than they hated slaves" (137). That Sethe should see in Bodwin an epitome of the slaveholder will not be a wonder to the reader. Still Morrison warns against the tendency to perpetrate violence. The community this time stops Sethe from repeating the mistake of the past by committing a second murder. As Adrienne Rich might see it, Beloved embodies the necessity "not to pass on a 
tradition but to break its hold over us" ("When" 19). This is clear in the narrative's final comment: "It was not a story to pass on" (274).

When the community exorcise the ghost of Beloved, they also manage to expel the ghost of Schoolteacher and the violence his figure is likely to incur. Beloved stands as a testimony to the grotesque decisions that slave women were forced to make and the terrible consequences they had to endure. Only in coalition with the community, will a woman like Sethe be able to break the spell of the past and live a healthy present. With Paul D's decision to "Put his story next to hers" (273), Sethe will overcome fragmentation of body and mind, the fragmentation that only long periods and excessive styles of oppression could cause. Sethe's narrative stands as testimony for the incredible sufferings of a people under oppression. By telling her own version of the truth, Sethe has exposed slavery's exploitation of certain forms of social studies for purposes of appropriation and domination.

The third chapter discusses Toni Morrison's analysis of travel and migration. Her novels, especially $\underline{\text { Jazz}}, \underline{\text { Sula }}$ and Tar Baby pinpoint the significance of honoring one's traditions as a means to overcome effects of the emotional affliction that betides the experience of travel and migration. In migrant countries, travelers are psychologically displaced because of their attempts to adapt to the bearing of new places and by virtue of their strife to be accepted among new people. To regain their emotional steadiness, migrants need to be permanently conscious of their past and their respective origins. Through the enduring recognition of the values and traditions of the old home, migrants are able to sustain a sense of who they are. Traditions do not necessarily restrict us to 
fixed positions, and people do not need to confine themselves to the domain of home in order to be able to relate to their original home values. 


\section{$\underline{\text { Notes }}$}

${ }^{1}$ I am using Michelle Burnham's explanation of Foucault's idea of agency.

${ }^{2}$ I am using Raymond Williams' phrase "convenient Formula." He employs the phrase as a comment on the way cultural studies sometimes pave the way for colonial appropriation. Williams talks about this at length in his book Culture and Society. The above quote is on p. 300 .

${ }^{3}$ Edward Said, Orientalism, p.88. Said is particularly critical of some area studies which have facilitated the project of colonialism. He gives the examples of Chateabriand's Itineraire, Lamartine's Voyage en Orient, Flaubert's Salambo, Lane's grnners and Customs of the Modern Egyptians, and Richard Burton's Personal Trative of a Pilgrimage to al-Madinah and Meccah.

${ }^{4}$ I am echoing Molly Abel Travis in "Beloved and the Middle Passage: Race Narrative, and the Critic's Essentialism," 183. 
On Questions of Travel: Morrison's Jazz $\underline{\text { Sula and Tar Baby }}$ 
Think of the long trip home.

Should we have stayed at home and thought of here?

Where should we be today?

Continent, city country, society:

the choice is never wide and never free.

And here, or there ... No. Should we have stayed at

home, wherever that may be?

Elizabeth Bishop, Questions of Travel

The image of traveller depends not on power, but on motion, on a willingness to go into different worlds, use different idioms, understand a variety of disguises, masks, rhetorics. Travellers must suspend the claim of customary routine in order to live in new rhythms and rituals. Most of all, and most unlike the potentate who must guard only one place and defend its frontiers, the traveller crosses over, traverses territory, abandons fixed positions, all the time.

Edward Said, "Identity, Authority and Freedom: The Potentate and the traveller."

This chapter analyzes themes of travel and migration present in Toni Morrison's

Jazz Sula and Tar Baby. Morrison's novels illustrate the dichotomies between North and South and between the metropolitan and indigenous rural settings. The Bluest Eye circles around the migration of Cholly and Pauline Breedlove to the North and the way migration has forever changed their lives. In the North, Pauline adopts the values of the hierarchical society and learns to adore the forms of beauty that white society embraces. Consequently she becomes unable to recognize the beauty of her husband and children and totally estranges herself from them. Beloved offers a distinction between a forced form of travel and a voluntary one. Moreover, Beloved's critique of the Middle Passage and its devastating effects on Africans is a unique example of forced travel. The hardship that Sethe goes through during her escape from slavery through the Ohio River 
is a commentary of forced travel and the manner in which slavery imposes grotesque decisions on its victims.

The narrative also explores themes of voluntary travels and Paul D's migration from one state to another signifies the voluntary movement of African-Americans after the Civil War. Denver's movement outside the domain of 124 Blue stone Road is another example of voluntary travel. The instance of Denver's move is significant since it illuminates the enlightening effects of leaving the fixed domains of one's home. When she ventures beyond the premises of 124 , she manages to save her mother from the ghost of the past and to regain her position within the community.

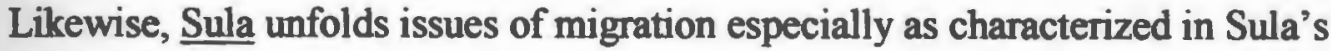
move from the Bottom to an anonymous urban site, her absence for ten years, and the effect her move has on the people she contacts after her return. Tar Baby explores themes of cultural impoverishment as embodied in Jadine's move to a European center and in the tension that Valerian Street sets up between Isle des Chevaliers and Philadelphia. Song of Solomon is especially important for its migration themes: Milkman attains personality growth as a result of his repeated visits to the South. Jazz explores themes of migration as the dichotomies between North and South are made clear through the migrants' experiences of both.

The tropes of migration present in Morrison's novels relate to the mass migration of African-Americans from the South to the North. Especially after the Civil War, the search for economic advancement and the need to escape racial oppression were among the driving forces behind the move of African-Americans to industrial Northern cities. 
This migration has had its significance in post-colonial discourse, and the uprooting of post-colonial populations has generated forms of resistance especially against the tangible racism of big cities. This chapter will analyze the themes of migration in three

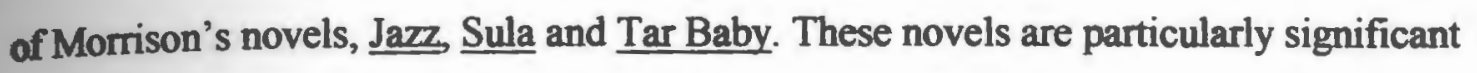
for emphasizing the importance of migration in producing sites for post-colonial resistance. The migration themes present in the three narratives are also a commentary on identity formation and resistance to hegemonic discourses.

In Jazz, the narrative foregrounds the search of the post-colonial subject for empowering historical roots and longer lasting values against the alienating styles of big cities. The quest for origins in $\underline{\text { Jazz }}$ is exemplified by Joe Trace's longing for rural living, the longing that follows the physical displacement of leaving one's place of origin for another geographical location. In the North, Joe Trace, Violet Trace and Alice Manfred become displaced victims: notwithstanding their attempts to integrate into the new place, they suffer from being members of a minority group. Migration is also associated with psychological displacement engendered by the migrants' struggle to plant themselves in the new environment and by their fear of having forever lost their homeland. Especially with Joe Trace, psychological displacement manifests itself in his attempts to substitute one form of behavior for another, trying to shed attributes of his former self as hunter in the woods and to adopt traits of a citified solicitor.

In Jazz, migrant characters like Joe Trace, Violet Trace and Alice Manfred are voluntary economic migrants. Joe and Violet's choice to leave the rural South for an urban industrial North came out of the need to improve their living conditions. In 
addition to their aspiration for economic and social advancement, the Traces' move was motivated by the need to escape the prevalent racial oppression of the South. Importantly, the narrative depicts the disabling influence of racial violence on both Violet and her mother Rose Dear. While in the South, Violet was haunted by the fear lest she would follow the same path of her mother's profound distress and end up in suicide. Rose Dear suffered separation from a nomadic spouse who traveled around the country, pursuing the cause of liberation for Southern black Americans. While waiting for her husband, Rose Dear was surprised by the arrival of white aggressors who destroyed her house and even snatched the chair from underneath her. Violet comments:

When they got to the table where our mother sat nursing an empty cup, they took the table out from under her and then, while she sat there alone, and all by herself like, cup in hand, they came back and tipped the chair she sat in. She didn't jump up right away, so they shook it a bit and since she still stayed seated- looking ahead at nobody- they just tipped her out of it like the way you get the cat off the seat if you don't want to touch it or pick it up in your arms ... No harm done if it is a cat because it has four legs. But a person, a woman, might fall forward and just stay there a minute looking at the cup, stronger than she is, unbroken at least and lying a bit beyond her hand. Just out of reach (98).

This incident of racial oppression aggravated Rose Dear's distress. Soon after that she committed suicide by jumping down a well.

After her mother's suicide, Violet was troubled by the image of a well and the threat of being devoured by it. Hence she struggles "against the pull of the well" (104), the same well that "sucked her sleep" (102). Violet's determination never to have children relates to her mother's suicide, to her fear lest she would do to her children what 
Rose Dear has done to her when she "dropped herself down the well and missed all the fun" (102). The possibility of Violet's repeating her mother's suicide builds in the continuance of the same conditions that brought about Rose Dear's death. Like Rose Dear, Violet internalized the racial violence perpetrated by white Southerners against blacks. Meditating over the circumstance that caused Rose Dear to leave her inert position sitting and jump down the well, Violet states,

What was the thing, I wonder, the one and final thing she had not been able to endure or repeat? Had the last washing split the shirtwaist so bad it could not take another mend and changed its name to rag? Perhaps word had reached her about the four-day hangings in Rocky Mount: the men on Tuesday, the women two days later. Or had it been the news of young tenor in the choir mutilated and tied to a $\log$, his grandmother refusing to give up his waste- filled trousers, washing them over and over although the stain had disappeared at the third rinse ... Or was it the chair they tipped her out of? Did she fall on the floor and lie there deciding right then that she would do it. Someday ... Seeing bleak truth in an unbreakable china cup? Biding her time until the moment returned- with all its mewing heart or overboard rage- and she could turn away from the door, the cup to step toward the limitless beckoning from the well. What could it have been, I wonder (101).

It is clear in this instant that Violet is projecting her own vulnerability to racial violence into her mother's fulfilled suicide. What might have pushed her mother to committing suicide could therefore be reason enough for Violet to repeat that act. Still Violet perceives the well antithetically as an oppressive space and a place of warmth and privacy. The narrator asserts, "Violet never forgot Rose Dear or the place she has thrown herself into, a place so narrow, so dark it was pure" (101-1). This dual perception of the 
well consists of Violet's fear of dying in it or by it and her paradoxical yearning to withdraw to its protective and hiding space. The well thereby becomes a symbol of Violet's psychological instability: while she is haunted by the "pull of a narrow well" (104), she still ponders over the purity of its narrowness.

Likewise, Violet's sense of home is dual: "As she grew older, Violet could neither stay where she was nor go away" (102). In the South Violet suffered from feelings of dislocation and separation, that is, wherever home was she did not feel at home since she was emotionally separated from it by circumstances of oppression. In the case of Violet, dislocation did not take place as a result of the traveler's attempt to acclimate to a new place. Rather, dislocation happened at home as a result of Violet's incapability to settle at home especially within its restraining conditions. Thus Jazz conceptualizes dislocation as a syndrome recurring mostly at home and prior to migration. The narrative of $\underline{\mathrm{Jazz}}$ embodies the notion that migration is not the only and primary condition of displacement. Prior to leaving their homelands, migrants like Violet and Joe Trace experienced feelings of dislocation and displacement. ${ }^{1}$ In Jazz displacement at home was brought about by racial oppression and economic houfficiency. Racism and poverty played major roles in Violet and Joe's decision to migrate North. It became difficult for the Traces to settle in the South, especially when they heard about the job opportunities available in the North. The narrator asserts, Their Baltimore dreams were displaced by more powerful ones. Joe knew people living in the city and some who' $d$ been there and come home with tales to make Baltimore weep. The money to be earned for doing light work- standing in front of a door, carrying food on a tray, even cleaning strangers' shoes- got you in a day more money than any of them had earned in one whole harvest (106). 
As Jocelyn Joshua Chadwick contends, the promise the city offers is "paradoxical in its nature" ("Metonymy"172). Migrants in the city are at the mercy of its precarious promises. The menial jobs allocated to African-American migrants have confined them, in Revathi Krishnaswamy's words, to a class of "Indentured laborers, subsisting on the margins of alien(ating) societies" ("Mythologies" 134). However, some migrants have found the city as fulfilling to its promise as possible. For Joe and Violet, the city becomes a "social facilitator" (Chadwick's phrase) since Joe picked up an easy job selling "Cleopatra products in the neighborhood" (128). The city as well was fair to Violet who took a job in hairdressing. Nevertheless, the narrator's sarcasm is covertly at work to expose the dual side of the city's promise of freedom. The narrator remarks, "The A\&P hires a colored clerk. Big-legged women with pink kitty tongues roll money into green tubes for later on. ... Nobody wants to be an emergency at Harlem hospital but if the Negro surgeon is visiting, pride cuts down the pain. ... I like the way the city makes people think they can do what they want and run away with it" (7). The city has offered only a restricted form of freedom. The A\&P has one black clerk only, black women still do the manual work of rolling money, and white people boycott the emergency room when the one black surgeon is in charge.

Migrants might get better social opportunities only at the price of becoming victims of racial and social discrimination. Jocelyn Joshua Chadwick comments on the manner in which Jazz exposes the city's specious generosity. She states, "What Morrison depicts over and over is the paradoxical promise that is at once positive and negative, and therefore, metamorphic, to all new comers as well as veterans in the city" 
Metonymy" 172). Even veterans of the city were deceived by its tantalizing promises. The narrative depicts the disenfranchisement and poverty of black migrants in the city. In Jarz, Morrison uncovers the exploitation of migrants as blue-collar workers. Once they are restricted to the "service capacity," migrants are also forced to inhabit the site of the margin. The world of the city therefore produces internal exiles consisting of the emotional and physical exile created at the margin. Internal exiles is illustrated in bell hooks' insight into the status of black Americans in industrial Kentucky. bell hooks asserts, "Across those [railroad] tracks was a world we could work in as maids, as janitors, as prostitutes as far as it was in a service capacity. We could enter that world but we could not live there" ("Marginality" 341). In the city, displacement consists in banishing migrants to marginal sites. In this sense, displacement is a post-migration condition due to the fact that migrants can enter the city without actually being part of it.

What mostly identifies the negative side of the city is its latent racism. Alice Manfred, for example, experiences the city's racism as insidious to her self-esteem. Despite the fact that she has done well as a seamstress, the city for her is a segregating place, a place where

Whitemen leaned out of motor cars with folded dollar bills peeping from their palms. It was where salesmen touched her and only her as if she were part of the goods they had condescended to sell her; it was the tissue required if the management was generous enough to let you try on a blouse (but not hat) in a store. It was where she, a woman of fifty and independent means had no surname. Where women who spoke English said, "Don't sit there, honey, you never know what they have." And women who knew no English at all and would never own a pair of silk stockings moved away from her if she sat next to them on the trolley (54). 
In the above instance, the narrative explicitly comments on the "hierarchical" differentiation of black women. In the city, Alice is doubly distressed by both gender discrimination and racism. A unique example of the city's racism is the murder of Alice Manfred's niece, Dorcas, which goes uninvestigated by the police. Joe Trace kills Dorcas when she abandons him for a younger lover. Outraged by both Joe's disloyalty and Dorcas's audacious act of stealing her husband, Violet tries to deface Dorcas' dead body with a knife. Alice Manfred abstains from having the police involved in either the killing of her niece or the attempted violation of that niece's corpse because she is wholly convinced that in the city black people are of little if any consequence. For Alice, Joe Trace and the corrupting atmosphere of the city are equally responsible for the murder of her niece. As she sees it, city debauchery stems out of its music and styles. Since she arrived in Harlem, Alice was confounded by the "race music" in which she "swore she heard a complicated anger in ... something hostile that disguised itself as flourish and roaring seduction. But the part she hated most was its appetite. Its longing for the bash, the slit ... It faked happiness, faked welcome, but it did not make her feel generous, this juke joint, barrel hooch, tonk house music" (57). From that kind of music, Alice tried in vain to protect her niece. The narrator states, "Alice Manfred has worked hard to privatize her niece, for she was no match to a city seeping music that begged and challenged each and every day. 'Come,' it said. 'Come and do wrong" (67). The manner in which Alice perceives city music as vile will hereafter help her deal with Dorcas' death. 
Alice's experience of city fashion is even more disconcerting than the way she relates to city music. She views fashion with inconsistency, that is, without being able to decide whether she likes it or not. Without admitting it, city styles have always enchanted Alice Manfred. The narrator exposes her dual sense of the city as exemplified in the manner she relates to its fashion: "High-heeled shoes with the graceful straps across the arch, the vampy hats closed on the head with brims framing the face, make up of any kind-all of that was outlawed in Alice Manfred's house. Especially the coats slung low in the back and not buttoned ... Privately Alice admired them, the coats and the women who wore them" (55). Once she views Dorcas' behavior from the angle of this paradoxical perception of the city, Alice Manfred begins to understand how it was unavoidable for Dorcas to be corrupted by the city's numerous temptations.

Still Alice Manfred has to figure out the dangerous tendency to violence city migrants like Joe Trace and his wife Violet have expressed. Hence she meditates, "the husband shot; the wife stabbed. Nothing. Nothing her niece did or tried could equal the violence done to her" (79). Ironically, Alice and Violet Trace come together in an attempt to understand not only the puzzle of Joe's murder of Dorcas but the pitfall of their surroundings. Out of their shared isolation, Alice and Violet come across the insurmountable barriers of Joe's murder of Dorcas and Violet's attack on the corpse to develop woman-bonding. Because she bonds with Violet, Alice will be able to excavate her internalized patriarchal oppression caused by her husband's abandonment when he took off with another woman. Through Violet's anger and her attempt to attack the dead body of her husband's young mistress Alice is encouraged to remember how at some 
point in her life she too was "starving for blood" (86). Like Violet, Alice never intended to direct her anger against the husband. Rather, her "craving settled on the red liquid coursing through the other woman's vein" (86). Violet enables Alice to recognize the immense pain her husband's disloyalty has cost her. On the other hand, Alice's company has helped Violet to recognize her own madness and to unravel her own identity no matter how "slow" and "degenerative" the process is (Barnes 291). With Alice, Violet is able to break her long-sustained silence, the silence that reflects on her inability to adapt to her new environment.

When she arrives in the city, Violet is mostly known as a "snappy, determined girl and a hard working young woman, with the sharp snatch-gossip tongue of a beautician" (23). Gradually, she develops unbreakable silences which "Over time annoy her husband, then puzzle him and finally depress him" (24). Violet's silence breaks only when she insists on being admitted into Alice's company. Together with Alice, Violet laughs at "that Violet," the other raggedy Violet that sits in the street, steals a baby, attacks a corpse in the casket and gets rid of her birds. Alice looks beyond the city's condemnation of Violet when she discovers in her a multifaceted Violet who is more than a just crazy and violent woman. What brings Alice and Violet together is not only their age similarity (since the two of them are in their fifties) or the shared feelings of loss (Alice's loss of her niece Dorcas and Violet's loss of her husband due to his love and murder of Dorcas) but also factors of their loneliness and isolation.

In $\mathrm{Jazz}$ the narrative depicts displacement as a condition brought about by the absence of a strong ethnic group identity. In their quest to acquire a citified image, 
migrants tend to turn their backs on their Southern values, neglecting mostly the importance of the community in sustaining a strong sense of individual and group identity. For example, the narrator is disappointed in the citified migrants Violet's customers represent, the ones who "wake up in the afternoon, pour gin in their tea" (13) and always "need their hair done" (14). From these migrant customers, Violet could never have the support that she needs, the thing which drives her to Alice Manfred's doors. As migrants, Alice and Violet locate displacement at the heart of the city and its inclusion of racism, isolation and comuption. Edward Said might see in their rallying "an enactment of a homecoming expressed through defiance and loss" ("Reflection" 358). Together Alice and Violet come to understand their shared feelings of loneliness and they also help each other to confront feelings of loss, especially the loss of homeland. Alice and Violet relate to each other through their shared struggle for self-realization and affirmation. Their quest for cultural healing in the collective sheds light on the postcolonial resistance embedded in the narrative of Jazz.

In an essay entitled "Cultural Hybridity in Tayeb Salih's Mousim al-Hijra ila alreason of Migration to the North)" Patricia Geesey defines the cultural hybrid as the "resulting offspring" of the contact between two disparate cultures (129). Jazz epitomizes the concept of hybridity as a result of the contact between two distinct cultures, especially in presenting Joe Trace as the offspring of the mixture between the culture of the South and that of the North. His awareness of his "mixed origins" creates in him the debilitating fear of having sacrificed his former cultural heritage. In Geesey's words, Joe Trace is "subject to the laws of cultural hybridity and contamination in a 
wist-colonial sense" ("Cultural" 36). In mourning the loss of his young mistress Dorcas, Joe Trace restricts himself within the confines of his apartment at Lenox. Since the death of Dorcas he takes to the permanent posture of sitting by a window, facing the city and "crying along with the glass pane" ( 118). Joe Trace's profound sadness expressed by "crying so openly" (118) is indicative of a state of melancholia brought about by mourning the loss of the beloved. Nevertheless, his self-imposed confinement at home should not be mistaken as acknowledgment of his responsibility in the murder of Dorcas. As suggested by his last name Trace, perhaps Joe Trace needs the murder of Dorcas in order to hold on to the trace, to the memory of his love for her. The narrative asserts, "He minds her death, is so sorry about it, but he minded more the possibility of his memory failing to conjure up the dearness" (28). By conjuring up images of lost objects, Joe Trace has been able to survive feelings of loss. Dorcas for him is like the memory of the rural scenes he has clung to in order to survive his alienation in the city. At some point, Joe Trace even conflates the memory of Dorcas with that of the country: "But all I lived through, all I seen, and not one of those changes prepared me for her. For Dorcas. You would have thought I was twenty, back in Palestine satisfying my appetites for the first time under a walnut tree" (129). The recurring images of trees signals Joe's struggle to come to terms with what he left behind, the country. According to Patricia Geesey, trees stand as symbol of "stability and rootedness" ("Cultural" 131). The manner in which he clings to memories of past incidents and to recollections of rural spots marks a need for colf-affirmation. The displaced migrant will often resort to memories in order to combat the fear that he/she might have lost a rooted sense of identity. 
Morrison's text entirely reflects on the phenomenon of displacement and expatriation experienced by Southern blacks migrating to the North. Caren Kaplan, for example, might see in Joe Trace an enactment of the "exile" who is both "melancholic and nostalgic about an irreparable loss and separation from the familiar or beloved" (Questions 30). According to Kaplan, "manifestations of nostalgia participate in EuropeAmerican constructions of exile: nostalgia for the past; for home; for a 'mother-tongue'; for the particulars that signify the experience of the familiar once it has been lost. Such nostalgia is rooted in the notion that it is 'natural' to be at 'home' and that separation from that can never be assuaged by anything but return" (Questions 33). In this instance Kaplan is talking about the Euro-American construction of modernist nostalgia. The narrative of Jazz depicts a form of nostalgia similar to the one Kaplan has mentioned. According to Richard Hardack, there is a "familiar enough modernist trope of selfalienation, of seeing oneself among ill-fitting popular culture [which] in Jazz is used to achieve a more dynamic critique of the American desire for a stable and self-containing male identity" ("A Music" 460). Particularly with the character of Joe Trace, Jazz epitomizes tropes of self alienation and nostalgia for irreparable losses. His inability to "achieve successful acclimation" in the new environment adds to his feelings of loss. ${ }^{2}$ The narrative thereby reminds us that it is "the city that develops a crooked kind of mourning" (111).

In Raymond Williams' words Jazz embodies "singular narrative of unsettlement, melessness, solitude and impoverished independence" (The Politics 34). In his voluntary seclusion, Joe Trace invents and clings to exile as implements of self- 
containment. Hence his solitary confinement is a defense mechanism against the "wasteland" atmosphere of the city. Bigger than his love for Dorcas or the memory of that love is Joe Trace's sense of him(self) as monolith: the murder of Dorcas has after all been engendered by his desire to assert his domination over her. Thus, he gives himself permission to kill Dorcas and then to grieve over her. The post-colonial theorist Renato Rosaldo would explain Joe Trace's despondency and his bountiful weeping in terms of imperialist nostalgia. As Rosaldo contends, "Imperialist nostalgia revolves around a paradox: A person kills somebody and then mourns the victim. In more attenuated form, someone deliberately alters a form of life, and then regrets that things have not remained as they were prior to intervention (Culture 69-70). Joe Trace's yearning for the beloved he himself killed is a clear example of imperialist nostalgia. Bewildered by the audacity of Joe Trace's murder of her niece, Alice Manfred wonders at "what she called the impunity of the man who killed her niece just because he could" (73).

The narrator of Jazz, who is also a migrant in Harlem, holds on steadily to the memory of rural settings she/he left behind. In referring to the volatile and often unstable nature of the city, the narrator insists on using country images, enhancing thus the inner perception of the country's malleability. The narrator states,

Nature freaks for you, then. Turns itself into shelter, byways. Pillows for two. Spreads the limbs of lilac bushes to hide you. And the city, in its own way, gets down at you. And the city, in its own way, gets down for you, cooperates smoothing its sidewalks, correcting its curbstones, offering you melons and green apples on the corner ... The city is smart at this: smelling good and looking raunchy; sending secret messages disguised as public signs: this way, open here, danger to let colored only single men on sale woman wanted private room stop 
dog on premises absolutely no money down fresh chicken free delivery fast. And good at opening locks, dimming stairways. Covering your moans with its own (64).

In this instance the narrative depicts the narrator's fear that she/he as well has been exposed to the same form of cultural "contamination" that has badly influenced the people she/he observes from her apartment. The fear of cultural "contamination" is associated with the migrants' apprehension that they have forever lost the "purity" of origin due to the contact with other cultures. Notwithstanding the fact that "pure" origins are only mythical, some migrants obsess over mouming the loss of their past "purity." In Jam, the narrator is apprehensive of the possibility that migrants have lost selfanthenticity by ceasing to be sincere to their primeval values and neglecting to abide by the traditions of the old home. Jazz portrays the migrants' disavowal of their former ideals, especially when they attempt to absorb city styles. The narrator therefore regrettably observes "how soon country people forget. When they fall in love with a city, it is forever, and it is like forever" (33). In adopting the stand of the composed writer, the narrator of Jazz manages to separate him/herself from other Harlem residents and also to divert the attention from her own cultural uncertainties. Despite the apparent reluctance to admit it, the narrator has been affected by the cultural "contact" between North and South. Hence, the narrator projects fears of his/her own displacement and rootlessness Onto other characters, especially when she implants in them dreams of "big trees. . bigger than those in the park" (43). 


\section{Moreover, the narrator betrays her implicit approval of and possible} mplicity?") in the murder of Dorcas when she openly proclaims, "I always believed that girl was a pack of lies" (72). It is quite possible that the narrator together with Joe Trace have both figuratively and literally killed Dorcas because she represents the city values they both want to eradicate. ${ }^{3}$ Central to the present concern is Richard Hardack's observation of how "each character derives his or her voice from this narcissistically echoing narrator" (“"Music" 463). Most probably the narrator has seen in Dorcas an epitome of the cultural "contamination" she also discerns in herself. Hence the narrator's approval of Dorcas' death stands evidence of his/her condemnation of the girl. The narrator accordingly struggles against the threat of cultural "contamination" by dreaming of more stable and better rooted locations.

Seen from a post-colonial perspective, the threat of cultural "contamination" is related with the experience of migration in general. Migration even affects the sensibilities of the ones who stayed behind, especially when they get in contact with those who came back from migrant places. In Sula, the community condemns Sula for the cultural "contamination" identifiable with "newcomers." The very manner of Sula's return to the Bottom immediately separates her from Bottom people: "Sula stepped off the Cincinnati Flyer into the robin shit and began the long climb into the Bottom. She was dressed in a manner that was as close to a movie star as anyone would ever see. A black crepe dress splashed with pink and yellow zinnias . . . a black purse . . . so small, so charming- no one had seen anything like it ever before, including the mayor's wife and the music teacher, both of whom had been to Rome" $(90)$. Due to her citified styles, the 
community immediately "classified" Sula as an "outsider." In Craig Werner's words, Sula came back literally "clothed with the image of the colonialist" (Studies 76). To the Bottom people, Sula's arrival was ominous, they related it to the plague of robins: "Accompanied by a plague of robins, Sula came back to Medallion" (89). For them, Sula now belonged to a different world and they were certainly destabilized by her introducing that world into their lives.

Despite her long absence, Sula feels at home in the Bottom. Apart from her manner of clothing, there is no evidence in the narrative to show that Sula is changed by her ten-year nomadic experience. Nonetheless, her own community will never feel at home with her presence in their midst. They see further evidence of Sula's assimilation of standards of the "white" world when she puts her grandmother Eva in a residential home and when she steals her friend Nel's husband. To them, Sula has exposed her own cultural "contamination," and they misinterpret Sula's styles as symptoms of her posttravel alienation from them. Bottom people are convinced that Sula is the bearer of some metropolitan ideology.

When the community denounces Sula as an alien, it remains oblivious to the fact that, as a woman, Sula has subsisted on the margin of the male-dominated world of the Bottom even prior to her departure. The community's strong preferences for lighter skinned women doubly confirms both Sula's and Nel's awareness of their marginality. The narrative remarks, "Because each had discovered years before that they were neither White nor male, and that all freedom and triumph was forbidden to them, they had set about creating something else to be" (52). Ironically, Sula is categorized an "outsider" 
only after spending ten years away from the Bottom. The community's failure to recognize the old Sula in the new one strategically sheds light on the arbitrariness of their rejection. Implicit in the narrative is the critique of the narrow scope of the community's judgment because it cannot see Sula as other than a traveling figure who is both unlike them and different from what she used to be.

The narrative also delves into the characters of the people of the Bottom to expose their sharing of attributes similar to the ones they condemned Sula for. For example, the narrator precisely opposes the naming of Sula as "pariah" for reasons of her easy styles when the people of the Bottom have completely forgotten their "own easy ways" (112). The men in the community are especially keen on deploring Sula for the "unforgivable thing," referring to her easy habits of sleeping with white men (112). Contradicting the community's claims to "purity" and their share in the "filthier" thing they accuse Sula of, the narrator comments,

The fact that their own skin color was proof that it had happened in their own families was no deterrent to their bile. Nor was the willingness of black men to lie on the beds of white women a consideration that might lead them toward tolerance. They insisted that all unions between white men and black women be rape; for a black woman to be willing was literally unthinkable. In that way, they regarded integration with precisely the same venom that white people did (113).

Central to this concern is Claudia Tate's observation that “the community in Morrison's fiction is never benign, and like all her other characters, community itself is morally mbiguous, comprising as it does a force for conformity, a demand for sanity, an argument for rationality- none of which qualities are desirable for either Morrison or her 
wilderness characters" ("Black" 53). Rather than sharing the community's moral ambiguity, Sula chooses to openly breach the norms of their double standards.

One question is whether the community would denounce Sula with such fervor if she had not left the Bottom. Immediately upon her return, the people constructed the myth of her alienation from them based on a plague of robins. When Sula's sexual encounter with Nel's husband Jude becomes known in town, they pronounce Sula a "roach" and the tale about her "watching Hannah [Sula's mother] burn was stirred again" (112). That they associate the evil in Sula with factors of her nomadism is implied in their never denouncing the ones who have stayed behind on grounds of misconduct similar to that of Sula's. While they reminisce over how Sula watched with "interest" her mother Hannah burn, they fail to remember how Eva herself burnt her son Plum. Ironically, Eva was never named "pariah," and Hannah was not denounced for her "easy ways" in the frequency of her sexual intimacy with married men. Roberta Rubenstein argues that Sula is "the dark shadow, the Other, that undermines both white and black fantasies of female goodness, beauty and upward mobility. Her position at the bottom of the bottom symbolizes the regrettable need to pronounce someone inferior in order to defend a fragile sense of self-worth" ("Pariahs" 130). In confining Sula as Fuderground" self, the community obtains identity and strength. The further Sula drifts from the community, the more important her presence becomes to them. The Bottom people want to set themselves against whatever evil Sula represents. The narrative asserts, "Their conviction of Sula's evil changed them in accountable yet mysterious ways. Once the source of their personal misfortune was identified, they had leave to love 
and protect one another. They began to cherish their husbands and wives, protect their children, repair their homes and in general band together against the devil in their midst" (117). The references in this passage to the community's act of recognizing itself against the limits of Sula are crucial. Morrison's narrative makes it clear that Sula after all is not much different from the people who condemn her.

Sula receives the community's contempt when she chooses not to recognize the limitations of her gender. Unlike her friend Nel, Sula refuses to marry in accordance with the traditions of the community. Rather than relying on marital or motherhood bonds to define her as a person, Sula builds a sense of identity by the deliberate dismissal of these bonds as norms. When Eva refers to Sula's single and motherless status as improper, Sula responds, "I don't want to make somebody else, I want to make myself" (92). By subverting the patriarchal rules embraced by the community, Sula becomes a threatening presence. The people of the Bottom believe that "she was laughing at their God" (115). The god that Sula refuses to solicit is the revered patriarchal and traditional deity whose "magic 'government' was going to lift them up, out and away from that dirt, those beans, those wars" $(160)$.

Rather than despairing over absences in their lives, the Bottom people occupy themselves with obsessing over Sula's aberration. The steadfastness of economic vafficiency forms one of the major absences among the Bottom community. People in the Bottom could not rely on agriculture because the Bottom is located on mountainous areas where land cultivation is backbreaking work. The white community of Medallion have literally displaced the black community when they ousted them to the hilly parts 
they -the white people- ironically named the Bottom. Medallion's white farmers managed to discharge the black residents of the fertile soil of the valley. They tricked a poor black farmer to accept the hilltop land rather than the promised bottom land which is more suitable for farming. The farmer was led to believe that hilltop land was closer to heaven, hence the naming of the hilly side of Medallion as Bottom to Heaven. The black community inhabiting the heights of Medallion are symbolically situated at the bottom of its economic and social stratum. By assigning the heights to black people, Medallion's white community manage to exclude blacks from agriculture, Medallion's major source of production. This literal displacement has created emotional displacement among the black community who misses real attachment to land or to any other substantial source of living. Patricia McKee contends that missing or absent attachments means a "massive "displacement"” ("Spacing" 4). Bottom people can only avoid factors of their displacement by obsessing over the evil in Sula. McKee writes of Sula, "By identifying Sula as evil and rejecting her categorically, people in the Bottom are able to keep their distance from absences they cannot afford to acknowledge" ("Spacing" 4).

The hopes of the Bottom people to benefit economically from the construction of a tunnel site are shattered as it turns out that white workers exclusively get hired for the job. When Bottom people spontaneously join Shadrack in celebrating his ritual of National Suicide Day, they end up destroying the tunnel site. The destruction of the tunnel marks the revolt against the economic obliteration of blacks by whites. mificantly, Bottom people begin to recognize their economic deprivation as a major 
absence only after Sula's death, when they cease to rely on her evil as a means to ward off reality. For example, Morrison asserts, "I wanted Sula to be missed by the reader. That's why she dies early" ("Spacing" 4). Commenting on Morrison's statement, McKee writes, "To miss Sula is to recognize her occupation in and of the Bottom: what she did there and how she was a necessary part of the place, not only as presence but also because she took the place of absence" ("Spacing" 4). Instead of dwelling over the absence of economic stability, the community of the Bottom occupied themselves with inventing Sula's difference from them. Sula's death becomes a major absence to the Bottom people, especially to her friend Nel. It takes Nel a long time to discover that it is Sula and not her husband Jude that she misses. Nel suddenly realizes that Sula after all is an integral part of herself, her own significant "other." To the Bottom, however, Sula remains the internal "other" whose irrationality has given them the urge to be rational. When Sula is absent, the people of the Bottom lose the wholesome outlook Sula's presence enabled. The massive deaths caused by the destruction of the tunnel indicates the exhaustion of the Bottom's potential to put up with major absences.

What Nel mostly misses in Sula is the latter's subversive nonconformity to the absolute conventions of the Bottom. Not until Eva reminds Nel of how she and Sula are "Just alike. Both of you. Never was no difference between you" (169), does Nel realize how much of Sula there is in her. Eva introduces Nel to a form of truth she has not yet Hiscovered in herself, the truth that "All these years she had been secretly proud of her calm, controlled behavior when Sula was uncontrollable, her compassion for Sula's fightened and shamed eyes. Now it seemed that what she had thought was maturity, 
serenity and compassion was only the tranquillity that follows a joyful stimulation" (170). In bemoaning Sula's death, Nel cries out, "We was girls together" (174). This is significant: Nel has willfully shared Sula's laughter at the town's dated traditions but has hidden her laughter behind her assumed conformity. Like the rest of town, Nel has condemned Sula less for her easy habits of sleeping with men and more for the fear of cultural "contamination" Sula presented ever since she came back to the Bottom.

What the narrative implicitly critiques is the community's adoption of the modern world's paradigms of "purity" and "monolithity." The persistent questioning of the anomalous and "discriminatory" status ascribed to Sula is the primary underlying theme of the narrative. Sula has been assigned the position of the migrant and diasporic and her impurity becomes foundational to the community's sense of itself as "pure." While the community condemns Sula as the breeder of alien ideologies, the narrative defends Sula as the positive hybrid. Homi Bhabha, for example, comments on the empowering effects of hybridity in that it "displays the necessary deformation and displacement of all sites of discrimination and domination. It unsettles the narcissistic or mimetic demands of colonial power [by reimplicating] its identifications in strategies of subversion that turns the gaze of the discriminated back upon the eye of power" (The location 112). In Sula, the narrative locates sites of discrimination and domination at the heart of the Dommunity's embrace of authoritarian and patriarchal traditions. Sula's hybridity is seen in light of her resisting practices against patriarchal replication and perpetuation of colonial hegemony. Instead of passively submitting to the Bottom's patriarchal traditions and their unjust demand for women to accept marital and maternal roles, Sula the hybrid 
refuses "to restore the image of authority to the eye of power" (The Location 112). maificantly, the narrative depicts Sula as neither an "outsider" to nor part of the Bottom. Also the narrative offers no indication that Sula has assimilated the values of the ("white?") world she left behind. For example, the narrative does not depict Sula as culturally destabilized by the long absence from her homeland. In Bhabha's words, Sula cccupies the "in-between space," that is, "the Third space of enunciations- that carries the burden on the meaning of culture" (The location 38). The third space the narrative of Sula embraces is the world that Sula herself occupies: a world which admits no fixed positions and completely abandons monolithic choices of either/or for the diverse orientations of both/and.

Like Morrison's other novels, Sula predicates tradition as a way out of social and psychological entrapment. The narrative covertly asserts the necessity to cast aside the old-fashioned patriarchal traditions of gender oppression. The narrative thereby abstains from either criticizing or apologizing for Sula's destruction of the patriarchal norms of the Bottom. Still Sula does not in any way invoke the modernist project and its advocating of the arbitrary overthrow of all forms of traditions. In a sense, Sula follows the line of Walter Benjamin's insistence on the indispensability of the continuous attempt to "wrest tradition away from a conformism that is about to overpower it" ("These" 681). Likewise, Sula advocates the endeavor to liberate traditions from smug conformism. In Sula, Morrison calls for the preservation of certain binding traditions. For example, she regrettably proclaims the disintegration of certain communal traditions 
caused by the community's adoption of the values of the modern world. The narrative states,

The black people, for all their new look, seemed awfully anxious to get to the valley, or leave town and abandon the hills to whoever was interested. It was sad, because the Bottom had been a real place. These young men kept talking about the community, but they left the hills to the poor, the old, the stubborn- and the rich white folks. Maybe it hadn't been a community, but it had been a place. Now there weren't any places left, just separate houses with separate televisions and separate telephones and less and less dropping by (166).

The narrative pinpoints the actual abandonment of the Bottom by its people.

Those who left the Bottom will probably not go back, and those who stayed behind have forgotten some important communal traditions. Unlike the migrants who leave without a chance of ever coming back, Sula returns to the Bottom. The narrative therefore remains uncritical of her temporary absence from the Bottom. However, the narrative critiques the manner in which Bottom people have negatively perceived Sula's absence by relating a plague of robins to her unexpected arrival. In Sula, Morrison abandons the adoption of ghetto mentality by refusing to confine her characters within narrowly defined cultural domains. ${ }^{4}$ Still the narrative is not negligent of the losses incurred by experiences of travel. For example, Eva returns to the Bottom with a leg mutilated. Nel's mother has her sense of identity troubled when on board the train the conductor calls her "girl." And Shadrack loses his sanity when he travels to fight a war and participate in the inhuman and unnecessary killing of others. 
Like Joe Trace and unlike Sula, Jadine in Tar Baby predicates the negative attributes of hybridity. Travel for Jadine is a major destabilizing force, rendering her ineparably dislocated. Jadine's travel in Europe is likely to disconnect her from ancestral and cultural roots. While in Europe, Jadine worked as a model and she obtained a degree in European art history. The narrative pinpoints the paradoxes of Jadine's success as a European art historian and her tremendous failure to grasp African tradition and folk culture. Her education in Paris was a form of compromise since it was subsidized by Valerian Street, the white industrialist who employs her uncle and aunt as butler and cook.

Jadine's cultural displacement is evident in the dilemma she faces when her European boyfriend proposes to marry her. Jadine is confident that he is the man she wants to marry; still she is not sure if he really wants her. Thus, she wonders if "the person he wants to marry is me or a black girl? And if it isn't me he wants, but any black girl who looks like me, talks and acts like me, what will happen if he finds out that I hate ear loops, that I don't have to straighten my hair ... that sometimes I want to get out of my skin and be only the person inside- not American- not black, just me" (48). This reflects Jadine's awareness that her possession of a white form of beauty is her only license into wealthy society. Jadine probably knows that her career in modeling is a form of compromise and this is likely to engender in her feelings of inauthenticity and cultural Fulnerability. For example, Jadine is emotionally destabilized by an African woman with a yellow dress who spits at her. The woman's insulting gesture makes Jadine feel out of place in Paris. So she immediately takes a flight out of Paris to Isle des Chevaliers, 
a small island on the Caribbean where Valerian Street and her aunt and uncle reside. The woman's gesture has derailing effects on her because Jadine fully understands its meaning: the woman Jadine wants to identify with as "sister/mother/she" (46) has entirely rejected her as member of the race. Jadine also identifies the woman in the yellow dress as the archetypal mother by virtue of "too much hip" and "too much bust" (45). To Jadine, she is the "woman's woman," the "unphotographable beauty," the "eyes whose force has burnt away their lashes" (46). What Jadine wanted from the woman is recognition, she "wanted that woman to like and respect her" (47). The woman instead shows only contempt and Jadine perceives the woman's disregard to be directed at her own rootlesseness. The incident is especially significant since it points out Jadine's distance from her African heritage. The gesture which forced Jadine out of Paris has also destabilized her sense of identity.

Her escape back to Isle des Chevaliers is most likely motivated by Jadine's search for roots, for a place she might identify with home. However, the island only reinforces Jadine's alienation from her own culture. She is displaced even among the people she calls family: she can not relate to the Streets, who sponsored her education, neither can she be daughter to the uncle and aunt who adopted her when she was twelve years old. To the black people in the community, Jadine is the daughter who estranged herself from them. In their solid rootedeness, the trees remind Jadine of her inappropriate separation from her roots. Alone in the woods, she imagines the presence of women hung from trees. Like the woman she encounters in Paris, the women she sees hanging from trees represent the stability and rootedness she herself lacks. The narrative comments, 
The young trees sighed and swayed. The women looked down from the rafters of the trees and stopped murmuring. They were delighted when they first saw her, thinking a runaway child had been restored to them. The women hanging from the trees were quiet now, but arrogant, mindful as they were of their own value, their exceptional femaleness; knowing as they did that the first world of the world had been built with their exceptional femaleness; knowing as they did that the first world of the world had been built with their sacred properties; that they alone could hold together the stones of pyramids and the rushes of Moses's crib; knowing their steady consistency, their pace of glaciers, their permanent embrace, they wondered at the girl's desperate struggle down below to be free, to be something other than they were (183).

This is crucial to our understanding of Jadine's cultural orphanage. Jadine has sacrificed her own cultural competency when she attempts to assimilate white values and norms. To the black people of Isle des Chevaliers, Jadine is now a complete stranger and has surely lost her connection with her ancestral roots in the African community. As Craig Werner might have it, Jadine's "struggle between two irreconcilable strivings threatens to plunge the black person trying to escape his or her native culture into a sort of halfway house, where that person is accepted neither as part of the European world nor part of the black one" (Studies 70). Jadine has obviously shunned African values for the white world in which she travels, the same white world that accepts her only as halfwhite and not as completely black.

When Jadine tires to reconnect with her ancestral roots through her romantic affair with Son, she fails. The African American lover she picks on the island will be to Jadine the nurturing ancestor she never had: "She wanted a little human warmth, some 
unsullied person to be near, so she took his hand without thinking about it and said "that's awful"" (210). Inherently, Jadine is aware of both her need for Son and Son's willingness to meet her needs. The text comments, "For the first time she saw his huge hands. One hand alone was big enough for two. A finger spread that could reach hither for you" (211). Son's immediate plan is to liberate Jadine from her subordination to the Streets. He wants to help Jadine out of her psychological entrapment to the Streets who sponsored her education, and he goes along with Jadine's plan to escape the Street's homestead.

In New York, Son is disoriented by the haunting gloominess he identifies with city dwellers. The discernible despondency of the city is especially typical of black women: "Black girls in New York City were crying and their men were looking neither to the right nor to the left. ... Oh, their mouths were heavy with plum lipstick and their eyebrows were a thin gay line, but nothing could stop their crying and nothing could persuade their men to look to the right or look to the left" (214). As in Jazz, The narrative of Tar Baby overtly comments on the disenfranchisement of black people in big cities. For example, the narrator comments on the manner in which the women's sadness has touched Son, "It depressed him all that crying, for it was silent and veiled by plum lipstick and thin gay lines over their eyes" (216). Jadine, on the other hand, remains unaware of the disconsolate people Son has noticed in New York. Once in the city, Jadine is so happy that she wants to "giggle" (221). New York is surely the place where she feels at home: "New York oiled her joints and she moved as though they were oiled. 
Her legs were longer here, her neck really connected her body to her head"' (221). Unlike Son, Jadine experiences the city as empowering.

Son's disappointment in New York invokes his dreams of Eloe, his original small town in North Florida. In Eloe, Jadine's identity crisis reaches its climax. As she sees it, Son and the rest of the black community of Eloe connect to women only in terms of petriarchal domination and control. Jadine's identity crisis takes the form of sexual fears and she dreams of "night women" who were "all there crowding into the room. Some of them she did not know, recognize, but they were all there spoiling her love making, taking her sex like succubi; but not his" (258). Son contradicts Jadine and he insists on explaining the economic independence and the indispensable role of the women in Eloe. The narrative states,

She kept barking at him about equality, sexual equality, as though he thought women were inferior. He could not understand that. Before Francine was attacked by the dogs, she gave him ten points on the court and still beat him... Cheyenne [Son's former wife] was driving a beat up old truck at age nine, four years before he could even shift gears, and she could drop a pheasant like an Indian. His mother's memory was kept alive by those who remembered how she roped horses when she was a girl. His grandmother built a whole cowshed only with Rosa's help. In fact the room that Jadine slept in, Rosa built herself which was why it didn't have any windows. Anybody who thought women were inferior didn't come out of north Florida (268).

No matter what Son says, Jadine is confirmed in her belief that women in Eloe are subjects to men's control especially in their acceptance of their role as mothers and 
protectors. As Jadine sees it, Eloe is still entrapped in a certain set of traditions in which men relate to women only as ultimate mothers.

Back in New York, Jadine and Son fight each other with relentless vehemence. Jadine wants to raise Son from the extreme poverty she identifies with Eloe and bind him to the world of finesse she relates to the city. Likewise, Son tries to pull Jadine away from what he sees as fraudulent city styles and he ardently resists her attempts to make him part of her world. In view of their irreconcilable differences, their romantic affair is inevitably fated. The narrator asserts,

Each was pulling the other away from the maw of hell- its very ridge top. Each knew the world as it was meant or ought to be. One had a past, the other the future and each one bore the culture to save the race in his hand. Mama-spoiled black man, will you mature with me? Culture bearing black woman, whose culture are you bearing (269).

This makes it clear that Jadine's and Son's worlds cannot meet. Outraged by Son's insinuating references to her cultural orphanage, Jadine finally takes a flight back to Paris.

In this final instance of Jadine's frequent travels lies the truth of Jadine's inability to recognize herself as a real human apart from travel. Only in adopting the cultural standards of some metropolitan site could Jadine come to a closer affirmation of her own identity. Still her onetime escape from Paris stands as an evidence of her awareness that she is not completely part of the Other world to which she continuously aspires. The certitude of Jadine's lack of cultural genuineness has prevented her from integrating into the world of Eloe. Evidence of her dislocation and separation is seen in her adoption of 
values different from those embraced by her own group. Son, on the other hand, goes back to the Isle des les Chevalier searching for Jadine. Marie Terese, a black ancestral figure, manages to convince him to "Forget her," adding that "There is nothing in her parts for you. She has forgotten her ancient properties" (305). Son decides to stay on the island and become one of its legendary knights, immersing himself further in his folk tradition and African roots. While the narrative covertly critiques Jadine's departure to Paris, it remains uninvolved in critiquing Son's decision to stay on the island. The Streets continue to reside on the island, living like prisoners in their big mansion and letting themselves be consumed by the guilt of having abused and neglected their only son.

Just as the narrative is overtly critical of Jadine's cultural precariousness, it also implicitly invalidates Eloe's patriarchal conventions and Son's conformity to them. Like Sula Tar Baby covertly calls out for a withdrawal from some of the traditions that overpower personal freedom. Tar Baby and Jazz focus on the negative aspects of the experience of hybridity. The three narratives advocate traditions as empowering tools against the alienating forces of expatriation. But the texts also emphasize the importance of shedding some traditions of the patriarchal control of men over women. Jazz invites the formation of ethnic group identity, while it cautions against blind absorption of city norms on the part of southern migrants. Sula advocates hybridity, especially when the hybrid resists assimilating the values of restrictive mother communities. While Sula insists on the importance of communal bonding, it is critical of the community's attempt

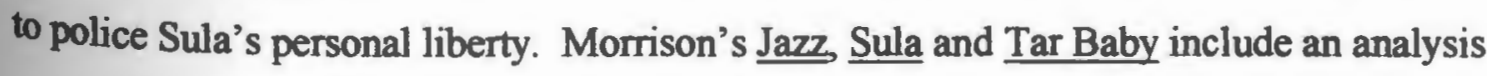


of how travel affects identity formation. The three texts call for resistance against assimilation in a post-colonial context.

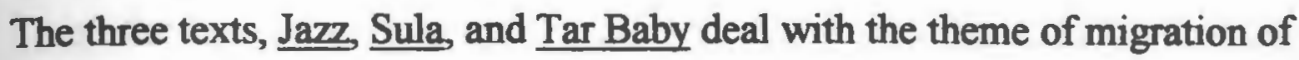
frican-Americans from the rural South to industrial Northern cities and the coexisting movement to metropoplitan sites. In the context of Morrison's narratives, migration is significant since it brings up themes of emotional displacement brought about by the physical move from one geographical location to the other. The migrant is displaced by the attempt to acclimate to the new place and by his/her awareness of factors of racism identifying metropolitan locations. The three narratives provide migrant people with tools of resistance consisting of communal bonding among migrants and adherence to one's cultural values and traditions. In the three narratives, Morrison also insists on casting out old-fashioned traditions which overpower freedom and bring about gender oppression. 


\section{Notes}

${ }^{1}$ I use the two nouns interchangeably and both usages should convey the same meaning, that is, one's incapacity to experience feelings of belonging to one's own home, especially when home offers no more than conditions of oppression and economic insufficiency.

${ }^{2}$ Caren Kaplan uses Elsa Triolet's argument that human beings are like plants and animals and that certain species cannot achieve successful acclimation, Questions of Travel, p. 33.

${ }^{3}$ This echoes Evalyn Accad's comment on Sa'eed's killing of the English woman he marries because she represents Western values that he wants to eradicate. Accad is quoted in Patricia Geesey's “cultural hybridity in Tayeb Salih's Mousim al-Hijra ila alShamal,, 134.

${ }^{4}$ Salman Rushdie warns against the adoption of ghetto mentality. In Imaginary Homelands, he reminds us not "to forget that there is a world beyond the community to which we belong, to confine ourselves within narrowly defined cultural frontiers, would be, I believe, to go involuntarily into that form of internal exile which in South Africa is called the "homeland" (19) 


\section{Conclusion}


Redeeming the past from the negative attributes related to it through systems of oppression is one of the major themes of postcolonial studies and literature. Postcolonial scholarship has strongly opposed the ongoing mechanisms of different systems of oppression to obliterate the past of subject peoples, the past that existed prior to an era of literal domination and cultural hegemony. The process of reclaiming the past necessarily entails the giving of voice and history for those who have been deprived of both. In a postcolonial context, reclaiming the past means more than a unitary or literal recording of historical facts. It rather requires victims of oppression to recover their submerged traditions and dig out buried communal memories as a means rewriting missing histories.

The search for a lost historical past gives subject peoples the chance to re-figure the present which is debilitated by different forms of cultural control. Morrison's novel Song of Solomon underscores the significance of re-evaluating the colonial past as an empowering weapon against the ongoing colonial hegemony and its imposition of white perspectives on subject peoples. When Milkman recovers the past of his family and its prominence in African-American traditions, he repudiates the habit of imitating the dictated styles of the dominant white culture. By rejecting the material values espoused by his father as a means of self-assertion, Milkman manages to liberate himself from emotional enslavement to a dominant society. Hagar, on the other hand, is a victim of the white culture she seeks to imitate, and her desperate effort to acquire white beauty brings about her hysteria and death. 
Whiteness as an acquired norm is also required in a society that valorizes white beauty. In order for Hagar to be able to meet the standards of her overbearing environment, she believes she has to assume the masquerade of the feminine as present in white beauty. As Mary Ann Doane might see it, masquerade in the case of Hagar is "pathological," because Hagar assumes the masquerade as a compensatory gesture. In this sense, the masquerade becomes a "position potentially disturbing, uncomfortable, and inconsistent, as well as physically painful to the woman" ("Masquerade" 47). What mostly intensifies Hagar's lack of self esteem is her inability to appreciate the merits of her own cultural values and traditions.

Likewise, the narrative of The Bluest Eye gives emphasis to past reclamation in order to empower the black female subject against the oppressive institutions of a white culture and its imposition of white images on black girls. In The Bluest Eye, the past is animated in the existing traditions of the black folk culture, consisting of folk song, communal traditions, and a carnival sense of life. Claudia MacTeer refrains from imitating white styles because of her awareness of the healing efficacy of the blues songs and her insight into the worth of the ancestor in the sustenance of folk values and traditions. Pecola, who remains ignorant of the significance of her own culture, seeks a white image as an alternative to (her)self, and goes insane in her quest to become white. In The Bluest Eye rehabilitation of an independent identity involves the radical erasure of the imposed white perspectives and their systematic replacement as an alternative vision. Traditions are instrumental in fracturing the colonial cultural control. 
Beloved reclaims the past on the part of those who have been silenced by the enormity of their experience in slavery. Reclaiming the past is a necessary condition of subjectivity, since it restores a voice and history to the oppressed people who have been deprived of the privilege of both. When the ex-slaves Sethe and Paul D break the silence over repressed memories of colonial oppression, they also write discourses of history that counteract different forms of colonial history. In this sense, redeeming the past involves breaking the traditions of silence that denied the oppressed their presence in history. To excavate repressed memories of past oppression, the narrative of Beloved suggests that colonial subjects bind together and orally exchange their shared troubles and physical wounds. Hence the narrative asserts the significance of the community and the necessity to hold to traditions of community cohesion. Only in uniting with the community will a woman like Sethe be able to break the spell of the past and live and be healthy in the present. With Paul D's decision to "put his story next to hers" (273), Sethe will be able to overcome vestiges of her oppressive history in slavery.

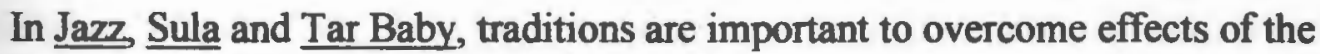
emotional affliction that betides experiences of travel. In migrant countries, travelers are Dsychologically displaced because of their attempts to adopt the bearing of the new place and be accepted by its people. To abate their emotional affliction, travelers must be conscious of their past and of their respective origins. Migrants are able to sustain a sense of who they are by virtue of the enduring recognition of the traditions of the old home. To be able to relate to their traditions and communal values, people need not confine themselves to the domain of home. Especially in Sula, Morrison insists that 
traditions should not fix us to one place. People's sense of their original values should stay with them wherever they are or go. To keep traditions alive we do not need to adopt the ghetto mentality that confines us to one place or one country.

Morrison's novels underscore the significance of reclaiming the past on the part of subject peoples. To dig out the traditions buried by long periods of colonialism is a major goal in reclaiming the past. Traditions in Song of Solomon and The Bluest Eye constitute a response against the overpowering styles of the "civilizing mission" existent in the propaganda for white beauty. In Beloved, Morrison proposes a reclamation of the past and a resurrection of communal traditions for purposes of cultural healing and identity recovery. The narrative of Beloved indicates that reclaiming the past on the part of the oppressed requires more than literal recording of historical facts. The process of recording history requires a rewriting of missing histories by allowing the victims to speak about their experiences in oppression. As Julia Kristeva sees it, to rewrite history is to embrace the "intra-subjective and the corporeal experience left mute by culture in the past" (in Anderson 195). The victims of oppression achieve intra-subjective recoding history when they get together and talk about mutual wounds and past suffering. Jazz,

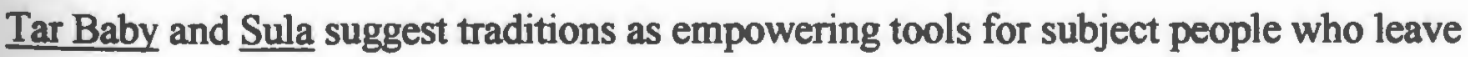
their old home and settle down in metropolitan countries. While the three narratives put emphasis on the necessity to embrace some traditions, they insist that people give up some traditions that no longer work. The narratives of Jazz, Sula and Tar Baby portray the characters' conflicts with one another, especially when each one of them tries to make decisions about which traditions to accept and which ones to reject. All of 
Morrison's texts give emphasis to the importance of reclaiming the past and redeeming valid traditions in the interest of personal and community recovery. 


\section{Bibliography}

Aijaz, Ahmad. In Theory: Classes, Nations, Literatures. London: Verso, 1992.

Anderson, Linda. "The Re-imagining of History in Contemporary Women's Fiction."

Ed Linda Anderson. Plotting Change: Contemporary Women's Fiction. London:

Edward Arnold, 1990.

Appiah, Kwame Anthony. In My Father's House: Africa in the Philosophy of Culture.

New York: Oxford University Press, 1992.

Barnes, Deborah H. 'Movin' on Up: The Madness of Migration in Toni Morrison's

“Jazz." Ed. Middleton L. David. Toni Morrison's Fiction: Contemporary

Criticism. New York: Garland, 1997.

bell hooks. "Marginality as Site of Resistance." Marginalization and Contemporary

Culture. Eds. Russell Fergusson et al. New York: The New Museum of

Contemporary Art, 1990.

Benjamin, Walter. "Theses on the Philosophy of History." Critical Theory Since 1965.

Eds. Hazard Adams and Leroy Searle. Florida: Florida University Press, 1992.

Bhabha, Homi K. The Location of Culture. London: Routledge, 1994.

-. "Of Mimicry and Man: The Ambivalence of Colonial Discourse." The

Location of Culture. London: Routledge, 1994.

-. "The Other Question: Difference, discrimination and the Other Discourse 
Discourse of Colonialism." In Theory: Marginalization and contemporary

Culture. Ed. Russell Fergusson, et al. New York: The New Museum of Contemporary Art, 1990.

Blair, Barbara. "Textual Expression for the Search of Cultural Identity." American Studies in Scandinavia 27 (1995): 48-63.

Chadwick, Jocelyn Joshua. "Metonymy and Synecdoche." The City in AfricanAmerican Literature. Eds. Yoshinobu Hakutani and Robert Butler. London: Associated University Press, 1995.

Cixous, Helene. "The Laugh of the Medusa." Critical Theory Since 1965. Eds. Hazard Adams and Leroy Searle. Florida State University Press: 1986.

Devlin, Kimberly J. "Pretending in 'Penelope': Masquerade, Mimicry and Molly Blooms." Molly Blooms: A Polylogue on "Penelope" and Cultural Studies. Ed. Richard Pierce. The University of Wisconsin Press, 1994.

Doane, Mary Ann. "Masquerade Reconsidered: Further Thoughts on the Female Spectator." Discourse: Journal for Theoretical Studies in Media and Culture (1988).

Fanon, Frantz. Toward the African Revolution: Political Essays. Trans. Haakon Chevalier. New York: Monthly Review Press, 1976.

Fergusson, Rebbeca. "History, Memory and Language in Toni Morrison's Beloved." Feminist Criticism. Ed. Susan Sellers. Toronto: The University of Toronto Press, 1991. 
Foucault, Michel. The History of Sexuality Volume I: An Introduction. Trans. Robert Hurdy. New York Vintage Books, 1978.

Geesey, Patricia. “Cultural Hybridity in Tayeb Salih's Mousim al-Hiira ila al-Shamal

(Season of Migration to the North)." Research In African-American Literature: Arabic Writing in Africa 28.3 (1997): 128-140.

Griffin, Farah Yasmine. "Who Set You Flowing?": The African American Migration

Narrative. New York: Oxford University Press, 1995.

Hardack, Richard. "A Music Seeking its Own words": Double Timing and Double Consciousness in Toni Morrison's Jazz." Callalo 18.1 (1995): 451-470.

Henderson, Mae G. “Toni Morrison's Beloved: Re-Membering the Body as Historical

Text." Comparative American Identities: Race, Sex, and Nationality in the

Modern Text. Ed. Hortense J. Spillers. New York, Routledge, 1991.

Kaplan, Caren. Questions of Travel: Postmodern Discourse of Displacement. Durham:

Duke University Press, 1996.

Krishnaswamy, Revathi. "Mythologies of Migrancy: Post-colonialism, Postmodernism and the Politics of (Dis)closure." Ariel 26.1 (1995):125-146.

Kristeva, Julia. "Women's Time." Critical Theory Since 1965. Eds. Hazard Adams and Leroy Searle. Florida State University Press, 1986.

Kuenz, Jane. "The Bluest Eye: Notes on History, Community, and Black Female Subjectivity." African American Review 27.3 (1993): 421-432.

Ledbetter, Mark. “An Apocalypse of Race and Gender: Body Violence and Forming Identity in Toni Morrison's Beloved." Picturing Cultural Values in Postmodern 
America. Ed. William G. Dotty. Tuscaloosa: The University of Alabama Press, 1995.

Lorde, Audre. "Race, Class, and Sex: Women Redefining Difference" Out There:

Marginalization and Contemporary Cultures. New York: The New York Museum of Contemporary Art, 1990.

Luchmann, Renate. "Bakhtin and Carnival: Culture as Counter-Culture." Cultural

Critique 11 (1988-89): 115-152.

Marshall, Brenda K. "Resisting Closure: Toni Morrison's Beloved." Teaching the Postmodern Fiction and Theory. New York: Routledge, 1992.

McKee, Patricia. "Spacing and Placing Experience in Morrison's Sula." Modern Fiction Studies 42.1 (1996): 1-23.

Millett, Kate. Sexual Politics. New York: Ballantine Books, 1969.

Mobley, Marilyn Sanders. Folk Roots and Mythic Wings in Sarah Orne Jewett and Toni Morrison. Baton Rouge: Louisiana State University Press, 1991.

Moore-Gilbert, Bart. Postcolonial Theory: Context, Practices, Politics. London: Verso, 1997.

Morrison, Toni. "Unspeakable Things Unspoken Spoken: The Afro-American Presence in American Literature." Criticism and the Color Line. Ed. Henry B. Wonham.

New Brunswick: Rutgers University Press, 1996.

-. Jazz. New York: Plume, 1993.--.

- Playing in the Dark: Whiteness and the Literary Imagination. New York:

Vintage Books, 1990. 
-. Beloved. New York: Knopf, 1987.

- Tar Baby. New York: Plume, 1983.

-. Song of Solomon. New York: Signet, 1977.

-. Sula. New York: Plume, 1973.

- The Bluest Eye. New York: Pocket Books, 1970.

Mulvey, Laura. Visual and Other Pleasures. Bloomington: Indiana University Press, 1989.

Rich, Adrienne. "When We Dead Awaken: Writing as Re-Vision." College English 34.1 (1972): 18-30.

Rigney, Barbara Hill. The Voices of Toni Morrison. Columbus: Ohio State University Press, 1991.

Rosaldo, Renato. "Imperialist Nostalgia" Culture and Truth: The Remaking of Social Analysis. Beacon Press, 1989.

Rubenstein, Roberta. "Pariah and Community." Critical Perspectives Past and Present Eds. Gates, Henry Louis, Jr. and K. A. Appiah. New York: Amistad Press, 1993.

Rushdie, Salman. Imaginary Homelands: Essays and Criticism 1981-1991. London: Granta Books, 1991.

Powell, Betty Jane. ““Will the Parts Hold?': The Journey toward a Coherent Self in Beloved." Colby Quarterly 771.1 (1995): 105-113.

Said, Edward. "Identity, Authority and Freedom: The Potentate and the Traveller." Source 1.2 (1991): 67-81. 
-. "Reflection on Exile." Out There: Marginalization and Contemporary

Culture. Ed. Russel Fergusson el al. New York: The New York Museum of Contemporary Art, 1990.

—. "Representing the Colonized: Anthropolgy's Interlocutors." Critical Inquiry 15.2 (1989): 205-25.

-. Orientalism. New York: Vintage Books, 1971.

Softing, Inger-Anne. "Camival and Black American Music as Counterculture in Toni Morrison's The Bluest Eye and Jazz." American Studies in Scandinavia. 27 (1995): 81-102.

Soyinka, Wole. The Burden of Memory, the Muse of Forgiveness. New York: Oxford University Press, 1999.

Tate, Claudia. "Black Women Writers at Work." Domestic Allegories of Political

Desire: The Black Heroine's Text at the Turn of the Century. Oxford: Oxford University Press: 1992.

Travis, Molly Abel. "Beloved and the Middle Passage: Race, Narrative, and the Critic's Essentialism." Narrative 2.3 (1994): 179-200.

Trees, Kathryn. "My Place as Counter-Memory." Journal of the South Pacific Association for Common Wealth and Language Studies 32 (1991): 66-47.

Wallace, Michelle. "Modernism, Postmodernism and the Problem of the Visual Art in Afro-American Culture." Ed. Russel Fergusson et al. Out There: Marginalization and Contemporary Culture. New York: The New York Museum of Contemporary Art, 1992. 
Werner, Craig. "New Democratic Vistas: Toward a Pluralistic Genealogy." Joseph

Weixlmann and Chester J. Fontenot. Eds. Studies in Black American Literature

II: Belief Vs. Theory. Greenwood, Fla.: Penkeville, 1986.

Williams, Raymond. The Politics of Modernism. Ed. Toni Pinkney. London: Verso, 1989.

-. Culture and and Society. New York: Columbia University Press, 1960.

Woidat, Caroline M. “Talking Back to Schoolteacher: Morrison's Confrontations with Hawthorne in Beloved" Archive Press. 39.3 and 4 (1994): 527-545. 